\title{
Deep South Atlantic carbonate chemistry and increased interocean deep water exchange during last deglaciation
}

Jimin $\mathrm{Yu}^{1,2^{*}}$, Robert F. Anderson ${ }^{3^{*}}$, Zhangdong $\mathrm{Jin}^{4}$, Laurie Menviel ${ }^{5,6}$, Fei Zhang ${ }^{4}$, Fredrick J. Ryerson ${ }^{2}$, Eelco J. Rohling ${ }^{1,7}$

${ }^{1}$ Research School of Earth Sciences, The Australian National University, Canberra, ACT 0200, Australia

${ }^{2}$ Lawrence Livermore National Laboratory, 7000 East Av., Livermore, CA, 94550, USA

${ }^{3}$ Lamont-Doherty Earth Observatory of Columbia University, 61 Route 9W/PO Box 1000, Palisades, NY, 10964-8000, USA.

${ }^{4}$ State Key Laboratory of Loess and Quaternary Geology, Institute of Earth Environment, Chinese Academy of Sciences, Xi'an 710075, China

${ }^{5}$ Climate Change Research Centre, University of New South Wales, Sydney, Australia ${ }^{6}$ ARC Centre of Excellence for Climate System

${ }^{7}$ Ocean and Earth Science, University of Southampton, National Oceanography Centre, Southampton SO14 3ZH, UK

*Correspondence to: jimin.yu@anu.edu.au (J.Y), boba@1deo.columbia.edu (R.F.A)

Submit to Quaternary Science Reviews as an Article

\section{Highlights:}

- New high-resolution $\left[\mathrm{CO}_{3}{ }^{2-}\right]$ for the deep S Atlantic during 0-28 kyr;

- Similar deep water $\left[\mathrm{CO}_{3}{ }^{2-}\right]$ between late Holocene and LGM;

- Deep water $\left[\mathrm{CO}_{3}{ }^{2-}\right]$ decreased, while $\delta^{13} \mathrm{C}$ rose during HS1;

- Interocean carbon exchange enhanced during HS1; 


\section{Abstract}

Carbon release from the deep ocean at glacial terminations is a critical component of past climate change, but the underlying mechanisms remain poorly understood. We present a 28,000-year high-resolution record of carbonate ion concentration, a key parameter of the global carbon cycle, at 5-km water depth in the South Atlantic. We observe similar carbonate ion concentrations between the Last Glacial Maximum and the late Holocene, despite elevated concentrations in the glacial surface ocean. This strongly supports the importance of respiratory carbon accumulation in a stratified deep ocean for atmospheric $\mathrm{CO}_{2}$ reduction during the last ice age. After $\sim 9 \mu \mathrm{mol} / \mathrm{kg}$ decline during Heinrich Stadial 1, deep South Atlantic carbonate ion concentration rose by $\sim 24 \mu \mathrm{mol} / \mathrm{kg}$ from the onset of Bølling to Preboreal, likely caused by strengthening North Atlantic Deep Water formation (Bølling) or increased ventilation in the Southern Ocean (Younger Drays) or both (Pre-boreal). The $\sim 15 \mu \mathrm{mol} / \mathrm{kg}$ decline in deep water carbonate ion since $\sim 10 \mathrm{kyr}$ is consistent with extraction of alkalinity from seawater by deep-sea $\mathrm{CaCO}_{3}$ compensation and coral reef growth on continental shelves during the Holocene.

Between 16,600 and 15,000 years ago, deep South Atlantic carbonate ion values converged with those at 3.4-km water depth in the western equatorial Pacific, as did carbon isotope and radiocarbon values. These observations suggest a period of enhanced lateral exchange of carbon between the deep South Atlantic and Pacific Oceans, probably due to an increased transfer of momentum from southern westerlies to the Southern Ocean. By spreading carbon-rich deep Pacific waters around Antarctica for upwelling, invigorated interocean deep water exchange would lead to 
more efficient $\mathrm{CO}_{2}$ degassing from the Southern Ocean, and thus to an atmospheric $\mathrm{CO}_{2}$ rise, during the early deglaciation.

Keywords: deep-sea, carbonate ion, interocean exchange, atmospheric $\mathrm{CO}_{2}$

\section{Introduction}

Ice core records reveal stepwise rises in atmospheric $\mathrm{CO}_{2}$ content since the Last Glacial Maximum (LGM; 22-18 kyr) (Monnin et al., 2001), but the reasons for these changes remain elusive. The large carbon reservoir of the deep ocean is thought to have played an important role in modulating past atmospheric $\mathrm{CO}_{2}$ changes (Broecker, 1982). A leading hypothesis for the deglacial atmospheric $\mathrm{CO}_{2}$ rise involves a breakdown of the deep vertical density stratification in the Southern Ocean (Anderson et al., 2009; Burke and Robinson, 2012; Sigman et al., 2010a) that governs the rate of $\mathrm{CO}_{2}$ exchange between the deep ocean and the atmosphere, a process commonly referred to as "ventilation". The history of deep water carbonate chemistry in the Southern Ocean is critical to inform us about the processes involved in the release of $\mathrm{CO}_{2}$ to the atmosphere in the past.

Deep water carbonate ion concentration, $\left[\mathrm{CO}_{3}{ }^{2-}\right]$, is an important parameter in deciphering the deglacial carbon cycle changes. To a first approximation, $\left[\mathrm{CO}_{3}{ }^{2-}\right] \approx$ ALK - DIC, where ALK is alkalinity and DIC is dissolved inorganic carbon, each of which influences the carbon storage in the ocean (Sigman and Boyle, 2000; Sigman et al., 2010a). Thus, a $\left[\mathrm{CO}_{3}{ }^{2-}\right]$ record for a key location such as the deep Southern Ocean 
would yield critical insights into the processes responsible for past atmospheric $\mathrm{CO}_{2}$ variations. Until now, a quantitative deep water $\left[\mathrm{CO}_{3}{ }^{2-}\right]$ record that can sufficiently resolve millennial timescale variability is lacking in the Southern Ocean. For example, a recently published deep water $\left[\mathrm{CO}_{3}{ }^{2-}\right]$ record from the Weddell Sea has only four data points during the last 30,000 years (Rickaby et al., 2010), limiting the use of these results to constrain the processes that have regulated the deglacial rise in atmospheric $\mathrm{CO}_{2}$. Here, we present the first high-resolution quantitative deep water $\left[\mathrm{CO}_{3}{ }^{2-}\right]$ record for the Southern Ocean spanning the last 28,000 years to constrain processes that controlled atmospheric $\mathrm{CO}_{2}$ variations in the past.

\section{Samples and methods}

Our reconstruction is based on measurements for sediment core TNO57-21 $\left(41.1^{\circ} \mathrm{S}, 7.8^{\circ} \mathrm{E}, 4,981 \mathrm{~m}\right)$ from the southern Cape Basin, South Atlantic Ocean (Fig. 1). The age model of the core is based on 3 new and 20 published radiocarbon dates (Fig. 2; Table S1) (Barker et al., 2009; Barker et al., 2010). It is impossible to use a single planktonic species for radiocarbon dating due to significant shell fragmentation at depths $0-80 \mathrm{~cm}$ (corresponding to $\sim 4-9 \mathrm{kyr}$ ) in TNO57-21 and the large sample size requirement for ${ }^{14} \mathrm{C}$ analysis. We thus used mixed planktonic species for our radiocarbon measurements. Radiocarbon dates are calibrated assuming a constant surface reservoir age of 600 years (Barker et al., 2009) using Calib 6.01 (Stuiver and Reimer, 1993) and the Marine 09 curve (Reimer et al., 2009). Using variable surface reservoir ages (Skinner et al., 2010) has negligible influence on our conclusion (Fig. $\mathrm{S} 1)$. The average sedimentation rate is $15.6 \mathrm{~cm} \mathrm{kyr}^{-1}$, which minimizes any influence from bioturbation and facilitates the development of climate records with excellent 
temporal resolution. The core site is bathed in Lower Circumpolar Deep Water (LCDW), which fills a large volume of the global deep ocean (Fig. 1). Changes in $\left[\mathrm{CO}_{3}{ }^{2-}\right]$ of LCDW thus have far-reaching implications for the global carbon cycle.

Our deep water $\left[\mathrm{CO}_{3}{ }^{2-}\right]$ reconstruction is based on $67 \mathrm{~B} / \mathrm{Ca}$ measurements of the epibenthic (a habitat above the sediment-water interface) foraminiferal species Cibicidoides wuellerstorfi (Table S2). About $10 \mathrm{cc}$ wet sediments for each sample (1 cm depth interval) from core TNO57-21 were disaggregated in de-ionized water and wet sieved through $63 \mu \mathrm{m}$ sieves. All C. wuellerstorfi, ranging from $\sim 15$ to 30 shells in each sample, were picked for all samples from the $250-500 \mu \mathrm{m}$ size fraction. The shells were then double checked under a microscope before crushing with due attention to use shells of most consistent morphology for $\mathrm{B} / \mathrm{Ca}$ analyses throughout the core, to minimize any potential influence from changes in shell morphology (Rae et al., 2011). In general, the starting material for each sample has $\sim 12$ to 25 shells, equivalent to $\sim 300$ to $600 \mu \mathrm{g}$. The shells were cleaned by the "Mg-cleaning" method (Barker et al., 2003; Yu et al., 2007) and B/Ca was measured on ICP-MS using the established procedure (Yu et al., 2005). Foraminiferal B/Ca shows no correlation with $\mathrm{Mn} / \mathrm{Ca}\left(\mathrm{R}^{2}=0.01, \mathrm{P}=0.55\right)$ or $\mathrm{Al} / \mathrm{Ca}\left(\mathrm{R}^{2}=0.00, \mathrm{P}=0.89\right)$ or $\mathrm{Fe} / \mathrm{Ca}\left(\mathrm{R}^{2}=0.00, \mathrm{P}=\right.$ 0.97) (Fig. S2), indicating that $\mathrm{B} / \mathrm{Ca}$ is not biased by contamination from diagenetic coatings or silicates.

\footnotetext{
C. wuellerstorfi $\mathrm{B} / \mathrm{Ca}$ ratios were converted to seawater $\left[\mathrm{CO}_{3}{ }^{2-}\right]$ using a sensitivity of $1.14 \mu \mathrm{mol} / \mathrm{mol}$ per $\mu \mathrm{mol} / \mathrm{kg}$ specific to this species, as obtained from a global core-top calibration $\left(\mathrm{Yu}\right.$ and Elderfield, 2007) by: $\left[\mathrm{CO}_{3}{ }^{2-}\right]_{\text {downcore }}=\left[\mathrm{CO}_{3}{ }^{2-}\right.$
} 
$131]_{\text {preindustrial }}+\Delta(\mathrm{B} / \mathrm{Ca}) / 1.14$, where the preindustrial $\left[\mathrm{CO}_{3}{ }^{2-}\right],\left[\mathrm{CO}_{3}{ }^{2-}\right]_{\text {preindustrial, is }}$

132 estimated using the GLODAP dataset (Key et al., 2004), and $\Delta(\mathrm{B} / \mathrm{Ca}$ ) is the deviation

133 of $\mathrm{B} / \mathrm{Ca}$ of down-core samples relative to the core-top value. The $\mathrm{B} / \mathrm{Ca}-\left[\mathrm{CO}_{3}{ }^{2-}\right]$ proxy

134 is empirical and the mechanism for the observed relationship remains largely

135 unknown. However, subsequent core-top (Brown et al., 2011; Rae et al., 2011;

136 Raitzsch et al., 2011; Yu et al., 2013a) and down-core (Raitzsch et al., 2011; Yu et al.,

137 2013a; Yu et al., 2010b) studies have strongly corroborated the faithfulness of the

$138 \mathrm{~B} / \mathrm{Ca}$ proxy for deep water $\left[\mathrm{CO}_{3}{ }^{2-}\right]$.

Based on core-top samples, Yu and Elderfield (2007) gave an uncertainty of

$141 \sim \pm 9 \mu \mathrm{mol} / \mathrm{kg}(2 \sigma)$ in deep water $\left[\mathrm{CO}_{3}{ }^{2-}\right]$ for reconstructions using C. wuellerstorfi

$142 \mathrm{~B} / \mathrm{Ca}$. This uncertainty should be treated as the worst scenario error because the

143 calculation included errors associated with hydrographic data (at $\sim \pm 5-10 \mu \mathrm{mol} / \mathrm{kg}$ in

144 seawater $\Delta\left[\mathrm{CO}_{3}{ }^{2-}\right]$ ) (Key et al., 2004), bioturbation (associated with sedimentation

145 rates), shell morphology influences, inter- and intra-shell variability, and analytical

146 error in $\mathrm{B} / \mathrm{Ca}$, all of which have been discussed in $\mathrm{Yu}$ et al. (2013a). Reconstruction

147 error in down-core records may be estimated using the variance in $\mathrm{B} / \mathrm{Ca}$ of duplicate

148 measurements and the sensitivity of $\mathrm{B} / \mathrm{Ca}$ to $\left[\mathrm{CO}_{3}{ }^{2-}\right]$. Down-core reconstruction

149 precision may differ between cores due to different degrees of bioturbation, and could

150 be improved by employing recommendations given in Yu et al. (2013a), which were

151 followed in this study. For example, the reconstruction error is given at $\sim 7 \mu \mathrm{mol} / \mathrm{kg}$

$152(2 \sigma)$ in core VM28-122 (Yu et al., 2010b). Unfortunately, it is impossible to make

153 duplicates for TNO57-21 due to the limited quantity of sediment available for this

154 study. Here, we assess the error based on the replicates of a consistency standard 
$155(\mathrm{~B} / \mathrm{Ca}=150 \mu \mathrm{mol} / \mathrm{mol})$, which was measured during the course of analyzing samples

156 from core TNO57-21 samples. The average uncertainty $(2 \sigma)$ of this consistency

157 standard is $\sim \pm 6 \mu \mathrm{mol} / \mathrm{mol}$ in $\mathrm{B} / \mathrm{Ca}$, corresponding to an error of $\sim \pm 5 \mu \mathrm{mol} / \mathrm{kg}(2 \sigma)$ in

158 seawater $\left[\mathrm{CO}_{3}{ }^{2-}\right]$ assuming a constant sensitivity of $1.14 \mu \mathrm{mol} / \mathrm{mol}$ per $\mu \mathrm{mol} / \mathrm{kg}$.

159 Compared to VM28-122, the slightly better reconstruction error for core TNO57-21 is 160 expected due to faster sedimentation rates at TNO57-21 $(\sim 15.7 \mathrm{~cm} / \mathrm{kyr}$ at TNO57-21

161 vs. $\sim 7 \mathrm{~cm} / \mathrm{kyr}$ at VM28-122), which would minimize bioturbation effects and thus be 162 conducive for improved reconstructions at TNO57-21.

We also measured U-Th isotopes for 36 sediment samples from TNO57-21 to supplement published data (Sachs and Anderson, 2003) and increase the resolution of $\mathrm{CaCO}_{3}$ and alkenone fluxes and of authigenic uranium during last 28,000 years (Fig. 2; Table S3). Uranium and thorium isotopes were measured in aliquots of the $1-\mathrm{cm}$ thick sediment samples from core TN057-21. Measurements were made by isotope dilution ICP-MS. A 0.5-g aliquot of dried sediment was dissolved using mixed acids in the presence of ${ }^{229} \mathrm{Th}$ and ${ }^{236} \mathrm{U}$ spikes. After weighing the final solution, an aliquot

$171(\sim 1.0 \%$ by weight $)$ was removed, spiked with ${ }^{230} \mathrm{Th}$ and additional ${ }^{236} \mathrm{U}$, and diluted with $1 \% \mathrm{HNO} 3+1 \% \mathrm{HF}$. This solution was analyzed without further processing by

173 ICP-MS to measure concentrations of ${ }^{238} \mathrm{U}$ and ${ }^{232} \mathrm{Th}$. Uranium and $\mathrm{Th}$ in the 174 remainder $(99 \%)$ of the initial solution were purified by anion exchange 175 chromatography, after which ${ }^{234} \mathrm{U},{ }^{235} \mathrm{U}$ and ${ }^{230} \mathrm{Th}$ were measured by ICP-MS. Details 176 of the method are presented in the work of Fleisher and Anderson (2003).

177 Calculations of $\mathrm{CaCO}_{3}$ and alkenone fluxes and authigenic uranium are given in 178 Sachs and Anderson (2003). 


\section{Dissolution effect on benthic B/Ca}

181

In the deep ocean, changes in deep water $\left[\mathrm{CO}_{3}{ }^{2-}\right]$ (deep water property) and dissolution of carbonate on the sea floor (including deep and pore water dissolution) are often coupled: when deep water $\left[\mathrm{CO}_{3}{ }^{2-}\right]$ is low, dissolution tends to increase and vice versa. This sometimes makes it difficult to distinguish whether a decline in benthic $\mathrm{B} / \mathrm{Ca}$ is due to a decrease in deep water $\left[\mathrm{CO}_{3}{ }^{2-}\right]$ or enhanced dissolution. However, strong evidence exists to argue against dissolution as the driver for changes in benthic B/Ca. First, benthic foraminiferal shells are calcified in corrosive deep waters and, when compared with planktonic shells, are more resistant to dissolution on the sea floor (Howard and Prell, 1994). Second, Rose Bengal stained (recently alive) and non-Rose Bengal stained (already dead and exposed to deep waters for a certain amount time) shells from the same core-top samples yield similar B/Ca ratios, suggesting that dissolution does not significantly affect $\mathrm{B} / \mathrm{Ca}$ ( $\mathrm{Yu}$ and Elderfield, 2007). Third, the sensitivity of $\mathrm{B} / \mathrm{Ca}$ to deep water $\Delta\left[\mathrm{CO}_{3}{ }^{2-}\right]$ is sustained at high $\left[\mathrm{CO}_{3}{ }^{2-}\right]$ ranges well above the saturation horizon where dissolution of carbonate is minimal (Raitzsch et al., 2011; Yu et al., 2013a; Yu and Elderfield, 2007), supporting that changes in $\mathrm{B} / \mathrm{Ca}$ are driven by changes in deep water $\left[\mathrm{CO}_{3}{ }^{2-}\right]$, not by dissolution.

An insignificant dissolution effect on benthic $\mathrm{B} / \mathrm{Ca}$ is further supported by comparisons of $\mathrm{B} / \mathrm{Ca}$ with dissolution proxies at core TNO57-21 (Fig. S3, S4). Overall, benthic B/Ca display weak correlations $\left(\mathrm{r}^{2}<0.10, \mathrm{P}>0.005\right.$; Fig. S4) with the $>63 \mu \mathrm{m}$ size fraction, foraminifera shell fragmentation $(>150 \mu \mathrm{m})$, and the whole shell number $(>150 \mu \mathrm{m})$, with the exception of $\% \mathrm{CaCO}_{3}$ in which case a significant 
correlation is observed (see below). Careful scrutiny of the data reveals that benthic $\mathrm{B} / \mathrm{Ca}$ and dissolution proxies have varied differently on millennial timescales. For example, benthic $\mathrm{B} / \mathrm{Ca}$ decreased and increased by $\sim 15 \mu \mathrm{mol} / \mathrm{mol}$ during the transitions into and out of Heinrich Stadial 2 (HS2; 27-24 kyr), respectively, which is not observed in any of the dissolution proxies (Fig. S3). During the LGM, benthic $\mathrm{B} / \mathrm{Ca}$ remained roughly stable, in contrast to obvious trends exhibited by dissolution proxies (steady increases in the $>63 \mu \mathrm{m}$ fraction, whole shell number and $\% \mathrm{CaCO}_{3}$

210 and a steady decline in fragmentation) (Fig. S3). At the transition from

211 Bølling/Allerød (B/A; 14.5-12.9 kyr) to Younger Dryas (YD; 12.9-11.8 kyr), benthic $\mathrm{B} / \mathrm{Ca}$ increased by $\sim 10 \mu \mathrm{mol} / \mathrm{mol}$, compared to substantial decreases in the $>63 \mu \mathrm{m}$

213 fraction and whole shell number, an increase in foraminifera shell fragmentation, and roughly stable $\% \mathrm{CaCO}_{3}$ (Fig. S3).

\section{Reliability of $\delta^{13} \mathrm{C}$ and $\mathrm{B} / \mathrm{Ca}$ in $C$. wuellerstorfi for deep water signals}

The fidelity of using epifaunal benthic foraminifera (e.g., Cibicidoides spp.) in reconstructions of deep water chemistry in the Southern Ocean is a matter of debate. It has been speculated that the extremely low $\delta^{13} \mathrm{C}$ in $C$. wuellerstorfi from the glacial deep Southern Ocean might be caused by their habitat preference in a fluff layer

221 where fluid $\delta^{13} \mathrm{C}$ is decreased by degradation of organic matter (the "Mackensen 222 effect") (Mackensen et al., 1993). If true, then respiration of biogenic matter should also increase DIC and decrease $\left[\mathrm{CO}_{3}^{2-}\right]$ of the microenvironment, resulting in concomitant decreases in $\delta^{13} \mathrm{C}$ and $\left[\mathrm{CO}_{3}{ }^{2-}\right]$ (this is also true for increased organic matter respiration in deep water). However, $\left[\mathrm{CO}_{3}{ }^{2-}\right]$ (this study) and $\delta^{13} \mathrm{C}$ (Ninnemann and Charles, 2002) at TNO57-21 display no correlation over the last 28,000 years and 
show opposite trends during Heinrich Stadial 1 (HS1; 17.5-14.5 kyr) (Fig. 2A, C). Furthermore, a recent core-top survey shows that Cibicidoides reliably records deep water $\delta^{13} \mathrm{C}$ in a wide region $\left(\sim 40-80^{\circ} \mathrm{S}\right)$ of the South Atlantic (Mackensen, 2012), and the low glacial benthic $\delta^{13} \mathrm{C}$ is highly reproducible at various locations from the Southern Ocean (Ninnemann and Charles, 2002). Based on the above, we interpret $\delta^{13} \mathrm{C}$ of benthic foraminifera at site TNO57-21 as a reliable recorder of the $\delta^{13} \mathrm{C}$ of DIC of bottom waters. From this we infer that processes other than the simple buildup and release of respiratory $\mathrm{CO}_{2}$ influenced the $\delta^{13} \mathrm{C}$ and $\left[\mathrm{CO}_{3}{ }^{2-}\right]$ of Cape Basin bottom waters in the past.

\section{Deep water $\left[\mathrm{CO}_{3}{ }^{2-}\right], \% \mathrm{CaCO}_{3}$, and ${ }^{230} \mathrm{Th}$-normalized $\mathrm{CaCO}_{3}$ flux}

Over the past $28 \mathrm{kyr}, \mathrm{B} / \mathrm{Ca}$-derived deep water $\left[\mathrm{CO}_{3}{ }^{2-}\right]$ shows similar largescale variations to sediment carbonate content $\left(\% \mathrm{CaCO}_{3}\right)$ and ${ }^{230} \mathrm{Th}$-normalized $\mathrm{CaCO}_{3}$ flux (Sachs and Anderson, 2003) (Fig. 2). Changes in deep water $\left[\mathrm{CO}_{3}{ }^{2-}\right]$ explain $43 \%$ of the variance in $\% \mathrm{CaCO}_{3}$ in $\mathrm{TNO} 57-21$ (Fig. S4). Although $\left[\mathrm{CO}_{3}{ }^{2-}\right]$ differs in detail from $\% \mathrm{CaCO}_{3}$ and $\mathrm{CaCO}_{3}$ flux due to secondary factors (see below), the overall agreement corroborates the notion (Anderson et al., 2008; Farrell and Prell, 1989; Hodell et al., 2001) that $\mathrm{CaCO}_{3}$ dissolution, regulated by deep water $\left[\mathrm{CO}_{3}{ }^{2-}\right]$, is a significant driver for $\mathrm{CaCO}_{3}$ abundance in sediments of the deep Cape Basin (Hodell et al., 2001), as well as in the deep Indian and Pacific Oceans (Anderson et al., 2008; Farrell and Prell, 1989; Yu et al., 2013a). 
Although they are broadly similar over the last 28,000 years (Fig. 2, S4d), sediment $\% \mathrm{CaCO}_{3}$ and deep water $\left[\mathrm{CO}_{3}{ }^{2-}\right]$ derived from $\mathrm{B} / \mathrm{Ca}$ in $C$. wuellerstorfi differ in detail. The differences include: (i) from 27-28 kyr to HS2, deep water $\left[\mathrm{CO}_{3}{ }^{2-}\right]$ declined, but $\% \mathrm{CaCO}_{3}$ remained low; (ii) $\% \mathrm{CaCO}_{3}$ displays a clear rising trend by $\sim 30 \%$ during the LGM, in contrast to roughly stable deep water $\left[\mathrm{CO}_{3}{ }^{2-}\right]$; (iii) the increase in $\% \mathrm{CaCO}_{3}$ halted, but showed no decline as observed in deep water $\left[\mathrm{CO}_{3}{ }^{2-}\right]$, during $\mathrm{HS} 1$; and (iv) sediment $\% \mathrm{CaCO}_{3}$ remained roughly constant from the $\mathrm{B} / \mathrm{A}$ to the Pre-Boreal (PB; 11.8-10 kyr), when deep water $\left[\mathrm{CO}_{3}{ }^{2-}\right]$ rose by $\sim 12 \mu \mathrm{mol} / \mathrm{kg}$ (Fig. 2A). These differences cannot be attributed to dilution of $\mathrm{CaCO}_{3}$ by detrital sediments 258 because $\% \mathrm{CaCO}_{3}$ and ${ }^{230}$ Th-normalized $\mathrm{CaCO}_{3}$ flux show very similar patterns over 259 the course of the past 28,000 years $\left(\mathrm{R}^{2}=0.95, \mathrm{n}=60, \mathrm{P}<0.0001\right)$ (Fig. 2B) (Sachs and Anderson, 2003). Dissimilar patterns of alkenone flux and $\% \mathrm{CaCO}_{3}$ indicate an 261 insignificant role of pore water dissolution in $\mathrm{CaCO}_{3}$ preservation in core TNO57-21 262 during the last $28 \mathrm{kyr}$ (Sachs and Anderson, 2003) (see Fig. 2B, S9c; SI text). We 263 attributed observed differences between $\% \mathrm{CaCO}_{3}$ and $\left[\mathrm{CO}_{3}{ }^{2-}\right]$ to secondary processes 264 affecting carbonate abundance in sediments, in addition to deep water $\left[\mathrm{CO}_{3}{ }^{2-}\right]$ changes. We speculate that sediment $\mathrm{CaCO}_{3}$ content and flux at the site of TNO57-21 are further influenced by factors including winnowing and focusing of fine carbonate 267 particles by deep currents (Sachs and Anderson, 2003) and changes in surface productivity (Karlin et al., 1992; Lyle et al., 2000; Sachs and Anderson, 2003). These secondary factors complicate the interpretation of $\mathrm{CaCO}_{3}$ accumulation quantitatively

270 in terms of deep-water $\left[\mathrm{CO}_{3}{ }^{2-}\right]$. By contrast, $C$. wuellerstorfi is an epibenthic species 271 that lives above the deep water-sediment boundary and hence records deep water 272 chemistry (Corliss, 1985; Lutze and Thiel, 1989). Benthic B/Ca methodology is based 273 on extensive core-top calibrations (Rae et al., 2011; Raitzsch et al., 2011; Yu et al., 
2013a; Yu and Elderfield, 2007) and its validity is strongly supported by down core studies (Raitzsch et al., 2011; Yu et al., 2013a; Yu et al., 2008; Yu et al., 2010c). In the text, we focus on $\mathrm{B} / \mathrm{Ca}$-derived deep water $\left[\mathrm{CO}_{3}{ }^{2-}\right]$ for paleoceanographic interpretations.

\section{LGM}

Deep water $\left[\mathrm{CO}_{3}{ }^{2-}\right]$ at TNO57-21 displays similar values during the LGM $(86.9 \pm 3.4 \mu \mathrm{mol} / \mathrm{kg}, \mathrm{n}=18,1$ standard deviation) and the late Holocene $(\sim 83.0$ $\mu \mathrm{mol} / \mathrm{kg}, \mathrm{n}=2,0-5 \mathrm{kyr}$ ) (Fig. 2A). Small changes in $\left[\mathrm{CO}_{3}{ }^{2-}\right]$ of $<\sim 5 \mu \mathrm{mol} / \mathrm{kg}$ between the Holocene and the LGM are also observed in the deep Indian and Pacific Oceans (Fig. 3; SI text) (Anderson and Archer, 2002; Yu et al., 2013a; Yu et al., 2010a). Assuming equilibrium between the surface ocean and the atmosphere, surface water $\left[\mathrm{CO}_{3}{ }^{2-}\right]$ would have been $\sim 60 \mu \mathrm{mol} / \mathrm{kg}$ higher than today (preindustrial) during the LGM (Foster, 2008; Lea et al., 1999; Yu et al., 2013b), when atmospheric $\mathrm{CO}_{2}$ was 90 part per million by volume (ppmv) lower (Fig. 4H) (Monnin et al., 2001). Although the spatial distribution of surface water $\left[\mathrm{CO}_{3}{ }^{2-}\right]$ in the world ocean during the LGM remains undetermined, it is reasonable to expect that the surface waters which contributed to newly formed deep water would have had a substantially higher preformed $\left[\mathrm{CO}_{3}{ }^{2-}\right]$ than today. The observation that LGM deep water $\left[\mathrm{CO}_{3}{ }^{2-}\right]$ was similar to the present therefore reveals an increased surface-to-deep $\left[\mathrm{CO}_{3}{ }^{2-}\right]$ gradient in the LGM ocean (Fig. 3). 
In seawater, remineralization of biogenic matter increases DIC but has little

297 influence on ALK, resulting in a net decrease in $\left[\mathrm{CO}_{3}{ }^{2-}\right]$. Therefore, the difference

298 between LGM and modern levels of respiratory $\mathrm{CO}_{2}$ in the deep sea must have been

299 sufficiently large to titrate the greater preformed $\left[\mathrm{CO}_{3}{ }^{2-}\right]$ of LGM surface waters down

300 to levels close to those existing in the modern deep ocean. This inferred increase in 301 respiratory $\mathrm{CO}_{2}$ in the glacial-age deep water is consistent with lower dissolved $\mathrm{O}_{2}$

302 concentrations in the deep Pacific Ocean during the LGM (Bradtmiller et al., 2010;

303 Galbraith et al., 2007; Jaccard and Galbraith, 2012). It is also consistent with

304 inferences of increased stratification in the glacial ocean (Burke and Robinson, 2012;

305 Lund et al., 2011), which, by limiting the ventilation of high-DIC deep waters, would

306 have facilitated the buildup of $\mathrm{CO}_{2}$ in the deep ocean and contributed to the low 307 atmospheric $\mathrm{CO}_{2}$ levels of the LGM (Sigman and Boyle, 2000; Sigman et al., 2010a).

\section{Deep South Atlantic $\left[\mathrm{CO}_{3}{ }^{2-}\right]$ evolution since the last deglacial}

After a $\sim 2 \mu \mathrm{mol} / \mathrm{kg}$ drop at the very end of the $\mathrm{LGM},\left[\mathrm{CO}_{3}{ }^{2-}\right]$ decreased by $\sim 7$

$311 \mu \mathrm{mol} / \mathrm{kg}$ at $\sim 16.6 \mathrm{kyr}$ during $\mathrm{HS} 1$ to a minimum of $\sim 77 \mu \mathrm{mol} / \mathrm{kg}$ at $15.6 \mathrm{kyr}$ (Fig. $2 \mathrm{~A}$,

312 4B). This decline in $\left[\mathrm{CO}_{3}{ }^{2-}\right]$ is independently supported by an increase in shell

313 fragmentation in the same core (Fig. S3) (Barker et al., 2010). A decrease of similar

314 magnitude in deep water $\left[\mathrm{CO}_{3}{ }^{2-}\right]$ at the location of TNO57-21 also occurred during

315 HS 2 (Fig. 2). This may imply a systematic link between Heinrich Stadials and

316 changes in deep South Atlantic $\left[\mathrm{CO}_{3}{ }^{2-}\right]$ chemistry, although $\left[\mathrm{CO}_{3}{ }^{2-}\right]$ changes during

317 previous Heinrich events are to be reconstructed. 
$321 \mathrm{~B} / \mathrm{A}$ (Fig. 4B). This increase in deep water $\left[\mathrm{CO}_{3}{ }^{2-}\right]$, together with the concurrent

$322>0.3 \%$ increase in benthic $\delta^{13} \mathrm{C}$ (Fig. 4C) (Ninnemann and Charles, 2002) and $\sim 160 \%$

323 rise in $\Delta \Delta^{14} \mathrm{C}$ [the offset between benthic and contemporary atmospheric $\Delta^{14} \mathrm{C}$ 324 (Reimer et al., 2009)] (Fig. 4D) (Barker et al., 2010), can be explained by rapid 325 ventilation of the deep South Atlantic by high- $\left[\mathrm{CO}_{3}{ }^{2-}\right]$ and ${ }^{14} \mathrm{C}$-enriched North 326 Atlantic Deep Water (NADW) (Fig. 1; 4A) (Barker et al., 2010; McManus et al., 327 2004). NADW reinvigoration is also thought to have been responsible for improved 328 carbonate preservation and for increases in both benthic $\delta^{13} \mathrm{C}$ and $\Delta \Delta^{14} \mathrm{C}$ at 3.3-3.6 km 329 water depth in the North Pacific at around 14.6 kyr (Fig. S5) (Galbraith et al., 2007). 330 This suggests widespread ventilation of the global abyss by low-DIC NADW, and a 331 sizable carbon loss from the deep ocean. Paradoxically, owing to an efficient 332 offsetting effect from an increase in the biological pump that enhanced respired DIC 333 at intermediate depths in the Indian and Pacific Oceans (Galbraith et al., 2007; Jaccard 334 and Galbraith, 2012), only a small net quantity of $\mathrm{CO}_{2}$ was released to the atmosphere 335 ( $\sim 10$ ppmv rise in atmospheric $\mathrm{CO}_{2}$ ) at the onset of $\mathrm{B} / \mathrm{A}$ (Fig. $\left.4 \mathrm{H}\right)$ (Monnin et al., 336 2001). 
associated with warming in Antarctica during the YD (Fig. 4I) (Barbante et al., 2006)

344 as simulated by (Menviel et al., 2011), and with intensified upwelling in the Southern

345 Ocean during the $\mathrm{YD}$ and $\mathrm{PB}$ as inferred from opal accumulation records (Fig. 4E)

346 (Anderson et al., 2009). Whatever combination of ventilation processes occurred in

347 the Southern Ocean, the associated release of $\mathrm{CO}_{2}$ from the deep ocean to the 348 atmosphere (SI Text) likely contributed to the initial $\sim 0.2 \%$ drop in $\delta^{13} \mathrm{CO}_{2}$ and 25

349 ppmv rise in atmospheric $\mathrm{CO}_{2}$ during the $\mathrm{YD}$ (Fig. 4G, H) (Monnin et al., 2001;

350 Schmitt et al., 2012).

Together with the concurrent $>0.2 \%$ increase in benthic $\delta^{13} \mathrm{C}$, the peak deep water $\left[\mathrm{CO}_{3}{ }^{2-}\right]$ of $\sim 104 \mu \mathrm{mol} / \mathrm{kg}$ at $10 \mathrm{kyr}$ in TNO57-21 (Fig. 4B, C) suggests that ventilation of the deep Cape Basin was further improved during the PB. At this time, besides sustained ventilation from the Southern Ocean (Fig. 4E) (Anderson et al., 2009), the deep Cape Basin ventilation was also affected by low-DIC and high- $\left[\mathrm{CO}_{3}{ }^{2-}\right.$ ] NADW (Fig. 1) as inferred from sediment Pa/Th (Fig. 4A) (McManus et al., 2004). During the $\mathrm{PB}$, atmospheric $\mathrm{CO}_{2}$ reached a plateau while atmospheric $\delta^{13} \mathrm{CO}_{2}$ rose (Fig. 4G, H) (Monnin et al., 2001; Schmitt et al., 2012). This suggests that the net release of $\mathrm{CO}_{2}$ from the deep ocean was in balance with net uptake by the terrestrial biosphere (Elsig et al., 2009). Insufficient data exist to assess how and where carbon

362 transfer between the deep-sea and the atmosphere occurred during this period. Based 363 on the coeval deep water $\left[\mathrm{CO}_{3}{ }^{2-}\right]$ increase at TNO57-21 and sustained high opal fluxes 364 south of the Antarctic Polar Front (Fig. 4E) (Anderson et al., 2009), we suggest that 365 degassing of $\mathrm{CO}_{2}$ via intensified upwelling in the Southern Ocean (SI Text) may have 
played a significant role in supplying the carbon required for forest regrowth during 367 the PB.

Since $10 \mathrm{kyr}$, deep water $\left[\mathrm{CO}_{3}{ }^{2-}\right]$ at TNO57-21 has plunged by $\sim 15 \mu \mathrm{mol} / \mathrm{kg}$,

370 while benthic $\delta^{13} \mathrm{C}$ in the same core has remained relatively stable (Fig. 4B, C). The

371 stable benthic $\delta^{13} \mathrm{C}$, which is sensitive to the accumulation of respiratory $\mathrm{CO}_{2}$,

372 indicates that the $\left[\mathrm{CO}_{3}{ }^{2-}\right]$ decline must have resulted from a greater decrease in 373 oceanic ALK than in oceanic DIC. This inferred ALK decrease is consistent with two 374 contributing factors inferred from modeling studies (Broecker and Peng, 1987;

375 Menviel and Joos, 2012; Opdyke and Walker, 1992; Ridgwell et al., 2003): (i) $\mathrm{CaCO}_{3}$ 376 compensation and (ii) burial of $\mathrm{CaCO}_{3}$ on continental shelves (SI Text). Owing to its 377 high sedimentation rate, our record reveals for the first time a clear acceleration of the $378\left[\mathrm{CO}_{3}{ }^{2-}\right]$ decline at $\sim 8 \mathrm{kyr}$ (Fig. 4B), when the substantial regrowth of corals on

379 continental shelves occurred (Vecsei and Berger, 2004). Detailed reconstruction of 380 deep water $\left[\mathrm{CO}_{3}{ }^{2-}\right]$ changes is critical for evaluating the influence of different factors 381 on Holocene atmospheric $\mathrm{CO}_{2}$ (Elsig et al., 2009; Menviel and Joos, 2012; Ridgwell 382 et al., 2003). Due to its detailed features and minimal influence from bioturbation at a 383 key location in the Southern Ocean, our record provides exceptional constraints for 384 models to better quantify the relative contributions of various processes to the 20 385 ppmv rise in atmospheric $\mathrm{CO}_{2}$ since $\sim 8 \mathrm{kyr}$ (Fig. 4H) (Monnin et al., 2001). 

HS1 (Fig. 4B), which contrasts with contemporary $\left[\mathrm{CO}_{3}{ }^{2-}\right]$ increases previously 390 observed in the deep Indian and Pacific Oceans (Yu et al., 2010a). It appears that the $391\left[\mathrm{CO}_{3}{ }^{2-}\right]$ decline mainly occurred during the late HS1 (14.5-16.6 kyr) (Fig. 4B). Twophase changes during HS1 have been observed in many, but not all (such as $\mathrm{Pa} / \mathrm{Th}$; Fig. 4A), high-resolution marine and ice core records (Broecker and Putnam, 2012).

394 Since our $\left[\mathrm{CO}_{3}{ }^{2-}\right]$ record is the first to resolve millennial timescale changes in the 395 deep South Atlantic, it would be premature at this stage to discuss two-phase $\left[\mathrm{CO}_{3}{ }^{2-}\right]$ 396 changes within HS1 without more records of equal resolution. We thus treat the $397\left[\mathrm{CO}_{3}{ }^{2-}\right]$ decline as occurring broadly during HS1, making no attempt to interpret 398 features within $\mathrm{HS} 1$. We acknowledge that if the two-phase $\left[\mathrm{CO}_{3}{ }^{2-}\right]$ change is 399 confirmed by additional records in the future, then our interpretation may need to be 400 revised. intensified upwelling in the Southern Ocean suggested by increased opal fluxes (Fig. 4E) (Anderson et al., 2009). Everything else being equal, transfer of $\mathrm{CO}_{2}$ from the 405 deep ocean to the surface ocean and the atmosphere by upwelling should deplete DIC 406 and hence increase $\left[\mathrm{CO}_{3}{ }^{2-}\right]$ in the deep Southern Ocean during HS1, opposite to our 407 reconstruction (Fig. 4B). The decrease in $\left[\mathrm{CO}_{3}{ }^{2-}\right]$ at TNO57-21 coincides with $\sim 0.2 \%$ o 408 increase in benthic $\delta^{13} \mathrm{C}$ (Fig. 4B, C) (Ninnemann and Charles, 2002), and this 409 combination rules out the possibility that the observed decline in $\left[\mathrm{CO}_{3}{ }^{2-}\right]$ during $\mathrm{HS} 1$ 410 reflects reduced penetration of high- $\left[\mathrm{CO}_{3}{ }^{2-}\right]$ and high- $\delta^{13} \mathrm{C}$ NADW relative to low$411\left[\mathrm{CO}_{3}{ }^{2-}\right]$ and low- $\delta^{13} \mathrm{C}$ LCDW (Fig. 1) (Key et al., 2004; Yu et al., 2010a). We can also 
412 dismiss a phytodetritus effect (Mackensen et al., 1993) on benthic $\delta^{13} \mathrm{C}$ based on the

413 high reproducibility of $\delta^{13} \mathrm{C}$ (Ninnemann and Charles, 2002) and the absence of any

414 correlation between $\delta^{13} \mathrm{C}$ and $\left[\mathrm{CO}_{3}{ }^{2-}\right]$ at TNO57-21 (Section 4). Any increased

415 organic matter respiration in deep water at the site would decrease both $\delta^{13} \mathrm{C}$ and

$416\left[\mathrm{CO}_{3}{ }^{2-}\right]$, which is not observed during HS1. Instead, we propose in the following a 417 new explanation that is consistent with all observations, which invokes increased 418 admixture of a deep Pacific water mass as the cause of the concurrent $\delta^{13} \mathrm{C}$ rise and $419\left[\mathrm{CO}_{3}{ }^{2-}\right]$ drop in the deep Cape Basin. by comparing reconstructed $\left[\mathrm{CO}_{3}{ }^{2-}\right]$ records from TNO57-21 and core MW91-9 GGC48 $\left(0^{\circ}, 161^{\circ} \mathrm{E}, 3,400 \mathrm{~m}\right)(\mathrm{GGC} 48$ hereafter) from the Western Equatorial Pacific (WEP; Fig. 1, 4B) (Yu et al., 2010a). The two cores also display large contrasts in benthic $\delta^{13} \mathrm{C}$ during the LGM, with Pacific values up to $\sim 0.5 \%$ higher, despite similar Holocene values (Fig. 4C) (Ninnemann and Charles, 2002; Yu et al., 2010a). The 428 lower glacial benthic $\delta^{13} \mathrm{C}$ at TNO57-21 does not necessarily imply a greater burden of respired $\mathrm{CO}_{2}$ at the site, because deep water $\delta^{13} \mathrm{C}$ is further influenced by factors

430 such as preformed values and air-sea exchange (Broecker and Maier-Reimer, 1992;

431 McCave et al., 2008). But benthic $\delta^{13} \mathrm{C}$ may be used to assess past deep water mixing 432 (Curry and Oppo, 2005), and we find the deep water $\delta^{13} \mathrm{C}$ in different sectors of the 433 Southern Ocean and in the equatorial Pacific Ocean displayed much larger contrasts 434 during the LGM, indicating reduced interocean exchange of deep water than today 435 (Fig. 5). In addition, a larger $\Delta \Delta^{14} \mathrm{C}$ gradient is observed between core TNO57-21 and 
WEP core MD01-2386 $\left(1.1^{\circ} \mathrm{N}, 130^{\circ} \mathrm{E}, 2,820 \mathrm{~m}\right)$ during the LGM (Fig. 4D) (Barker et al., 2010; Broecker et al., 2007; Key et al., 2004), further supporting the inferred glacial reduction in the interocean exchange of deep water.

Overall, therefore, we infer that the LGM ocean was characterized not only by reduced vertical mixing associated with enhanced stratification (Burke and Robinson, 2012; Lund et al., 2011), but also by an increased chemical dissimilarity between deep waters in the Atlantic and Pacific Oceans (Fig. 4B-D, 5). This combination supports the view (McCave et al., 2008) that deep water masses in the world's ocean basins were physically more isolated from each other during the LGM due to reduced lateral exchange via the Southern Ocean.

During the early deglaciation, the deep water $\left[\mathrm{CO}_{3}{ }^{2-}\right]$ gradient between TNO57-21 and GGC48 started to diminish, as $\left[\mathrm{CO}_{3}{ }^{2-}\right]$ at TNO57-21 fell and $\left[\mathrm{CO}_{3}{ }^{2-}\right]$ at GGC48 rose (Fig. 4B) (Yu et al., 2010a). The deep water $\left[\mathrm{CO}_{3}{ }^{2-}\right]$ at both sites reached comparable values during late HS1 ( 15.8-14.6 kyr), the only time when complete convergence in $\left[\mathrm{CO}_{3}{ }^{2-}\right]$ occurred over the last 28,000 years (Fig. 4B). During HS1, benthic $\delta^{13} \mathrm{C}$ and $\Delta \Delta^{14} \mathrm{C}$ at site TNO57-21 also converged with those at 3.4 and $2.8 \mathrm{~km}$ water depths in the WEP, respectively (Fig. 4C, D), as well as with those at $3.8 \mathrm{~km}$ water depth in the South Atlantic (Skinner et al., 2010) and 2.7-3.6 km water depth in the North Pacific (Galbraith et al., 2007) (Fig. S5, S6). 
A change in each of our examined proxies by itself may be caused by multiple processes. For example, benthic $\delta^{13} \mathrm{C}$ is further influenced by factors in addition to

460 interocean exchange of deep water, including gas exchange and preformed water 461 chemistry. Benthic $\Delta \Delta^{14} \mathrm{C}$ may be complicated by changes in surface reservoir ages, 462 but this has negligible influence on the HS1 $\Delta \Delta^{14} \mathrm{C}$ convergence between deep South 463 Atlantic and Pacific records (Fig. S7). However, an extraordinary coincidence would 464 be required to explain the convergence observed in all three proxies by invoking 465 simultaneous changes in the preformed chemistry of the different water masses. 466 Instead, it is most straightforward to attribute the concurrent convergence of all three 467 proxies to better mixing of deep waters between the South Atlantic and Pacific 468 Oceans during HS1 than during the LGM. Our interpretation is also consistent with a 469 wider suite of geochemical proxies including neodymium isotopes and authigenic 470 uranium from TNO57-21 (Fig. S8, S9; SI text) (Piotrowski et al., 2012; Piotrowski et 471 al., 2005; Sachs and Anderson, 2003). It is worth noting that increased interocean 472 deep water exchange during HS1 differs from ventilation of global abyssal ocean at 473 the onset of B/A (see above), when the formation of low-DIC NADW was much 474 strengthened compared to HS1 (Fig. 4A) (McManus et al., 2004).

\section{Mechanism and implication for deglacial atmospheric $\mathrm{CO}_{2}$ rise} is roughly coeval with the intensified upwelling and breakdown of deep vertical stratification in the Southern Ocean during the rapid warming in Antarctica (Fig. 4E,

480 I) (Anderson et al., 2009; Barbante et al., 2006). The synchronicity of these events 481 suggests that they may be linked to one another by a common mechanism. Northern 
Hemisphere insolation-induced fresh water input into the North Atlantic at last glacial termination led to a reduction of NADW formation during HS1 (Fig. 4A) (He et al., 2013; Liu et al., 2009; McManus et al., 2004). Through atmospheric teleconnections, a NADW shutdown may also cause poleward displacement or strengthening of the Southern Hemisphere westerlies (McGlone et al., 2010; Putnam et al., 2010), as invoked previously to account for increased opal fluxes in the Southern Ocean (Fig. 4E) (Anderson et al., 2009). Changes in the southern westerlies may have increased lateral (zonal) exchange of deep waters around Antarctica (Ho et al., 2012) through more efficient transfer of momentum from the winds to the ocean at the critical latitudes of the Drake Passage (Toggweiler et al., 2006), while also enhancing the meridional overturning in the Southern Ocean via Ekman pumping (Anderson et al., 2009; Morrison and Hogg, 2013; Toggweiler et al., 2006) (Fig. 6).

The deep Pacific Ocean stores the largest amount of carbon in the ocean-land biosphere-atmosphere system today (Broecker, 1982; Key et al., 2004), and proxies suggest an even larger carbon stock in the deep Pacific during the LGM (Bradtmiller et al., 2010; Jaccard and Galbraith, 2012). Reduced glacial interocean mixing would have facilitated storage of low- $\left[\mathrm{CO}_{3}{ }^{2-}\right]$, old- ${ }^{14} \mathrm{C}$, low- $\mathrm{O}_{2}$ (Bradtmiller et al., 2010; Galbraith et al., 2007; Jaccard and Galbraith, 2012) and, presumably, high-DIC waters in the deep Pacific Ocean (Fig. 1, 4B-D), contributing to low atmospheric $\mathrm{CO}_{2}$ during the LGM (Fig. 4H) (Monnin et al., 2001). Whatever the nature of the physical processes responsible for increased lateral mixing during HS1, they must have contributed to the ventilation of $\mathrm{CO}_{2}$ from the deep Pacific. Interocean exchange of deep waters is constrained to occur via the Southern Ocean, where enhanced vertical mixing during HS1 was recorded by the burial flux of biogenic opal (Fig. 4E) 
507 (Anderson et al., 2009). Consequently, it is reasonable to infer that a portion, although

508 not necessarily all, of the deep water exchanging between the South Atlantic and

509 Pacific Oceans was subject to entrainment by the processes driving vertical mixing,

510 thereby enhancing the ventilation of DIC previously stored in deep Pacific waters.

Geochemical tracers cannot be used to quantify the relative contributions by vertical and lateral deep water exchange to the deglacial increase in deep ocean ventilation, but they inform us that both occurred. Recent modeling suggests that transport by the Antarctic Circumpolar Current (ACC; linked to lateral deepwater

516 exchange) is much less sensitive to changes in the southern westerlies than is meridional overturning circulation (Morrison and Hogg, 2013). However, the westerlies in their model runs are in a modern poleward-shifted position, under which condition ACC is possibly in an eddy-saturated state. By contrast, the transition from the LGM to HS1 might involve a much larger poleward shift in the position of the

521 westerlies (possibly beginning from a position during the LGM equatorward of their modern location), which could impose a stronger impact on Southern Ocean hydrography. In light of the compelling evidence for homogenization of deep waters during HS1, and the implications for understanding climate-related changes in atmospheric $\mathrm{CO}_{2}$, we hope that our findings will encourage investigators to dig deeper

526 into the processes involved and help reconcile the physical oceanographic models with paleoceanograhic observations.

\section{Conclusion}


Using a high-resolution reconstruction of $\left[\mathrm{CO}_{3}{ }^{2-}\right]$ in the deep South Atlantic,

531 we describe the sequence of events that shaped the ocean carbon cycle and

532 atmospheric $\mathrm{CO}_{2}$ since the last ice age. During the initial phase of deglaciation,

533 increased lateral exchange of deep water between the Pacific and Atlantic Oceans

534 enhanced the ventilation of $\mathrm{CO}_{2}$ from the deep sea by the contemporary

535 intensification of vertical mixing. The initial chemical signature of North Atlantic

536 Deep Water occurred during the Bølling ( 14.5 kyr), while the principal Holocene

537 feature of the record indicates extraction of alkalinity from seawater by $\mathrm{CaCO}_{3}$

538 deposition on continental shelves. Our study provides an unprecedented high-

539 resolution deep water $\left[\mathrm{CO}_{3}{ }^{2-}\right]$ record in the South Atlantic to improve our

540 understanding of the global carbon cycle in the past.

\section{Acknowledgments}

544 Core material used in this study was provided by the Lamont-Doherty Earth 545 Observatory Deep-sea Sample Repository. We thank W.S. Broecker, X. Wang, P. De 546 Deckker, S. Eggins, and B. Opdyke for discussions, P. Tomascak, B. Yan, and P. 547 Wang for laboratory assistance, and Robbie Toggweiler and two anonymous 548 reviewers for comments. This work is supported by ARC DP140101393, the 549 Lawrence Livermore National Laboratory's Lawrence Fellowship Program, a 550 Lamont-Doherty Postdoctoral Fellowship, and a Comer Science and Education 551 Foundation Fellowship (JY), and the CAS/SAFEA International Partnership Program 552 for Creative Research Teams (JY/ZJ), the US NSF (RFA; OCE 0823507), and 553 contribution from Laureate Fellowship FL120100050 (EJR).

\section{Author contributions}

556 J.Y. designed and managed the project and measured B/Ca. R.F.A. measured Th-U. 557 J.Y. and R.F.A. developed interpretation and wrote the manuscript with assistance 558 from all authors. Z.J. and F.Z. picked and prepared benthic foraminifera for B/Ca and $559{ }^{14} \mathrm{C}$ dating. All authors commented on the manuscript. 


\section{References}

562

563

564

565

566

567

568

569

570

571

572

573

574

575

576

577

578

579

580

581

582

583

584

585

586

587

588

589

590

591

592

593

594

595

596

597

598

599

600

601

602

603

604

Anderson, D.M., Archer, D., 2002. Glacial-interglacial stability of ocean pH inferred from foraminifer dissolution rates. Nature 416, 70-73.

Anderson, R.F., Ali, S., Bradtmiller, L., Nielsen, S.H.H., Fleisher, M.Q., Anderson, B.E., Burckle, L.H., 2009. Wind-driven upwelling in the Southern Ocean and the deglacial rise in atmospheric $\mathrm{CO}_{2}$. Science 323, 1443-1448.

Anderson, R.F., Fleisher, M.Q., Lao, Y., Winckler, G., 2008. Modern $\mathrm{CaCO}_{3}$ preservation in equatorial Pacific sediments in the context of late-Pleistocene glacial cycles. Mar. Chem., doi:10.1016/j.marchem.2007.1011.1011.

Barbante, C., Barnola, J.M., Becagli, S., Beer, J., Bigler, M., Boutron, C., Blunier, T., Castellano, E., Cattani, O., Chappellaz, J., Dahl-Jensen, D., Debret, M., Delmonte, B., Dick, D., Falourd, S., Faria, S., Federer, U., Fischer, H., Freitag, J., Frenzel, A., Fritzsche, D., Fundel, F., Gabrielli, P., Gaspari, V., Gersonde, R., Graf, W., Grigoriev, D., Hamann, I., Hansson, M., Hoffmann, G., Hutterli, M.A., Huybrechts, P., Isaksson, E., Johnsen, S., Jouzel, J., Kaczmarska, M., Karlin, T., Kaufmann, P., Kipfstuhl, S., Kohno, M., Lambert, F., Lambrecht, A., Lambrecht, A., Landais, A., Lawer, G., Leuenberger, M., Littot, G., Loulergue, L., Luthi, D., Maggi, V., Marino, F., Masson-Delmotte, V., Meyer, H., Miller, H., Mulvaney, R., Narcisi, B., Oerlemans, J., Oerter, H., Parrenin, F., Petit, J.R., Raisbeck, G., Raynaud, D., Rothlisberger, R., Ruth, U., Rybak, O., Severi, M., Schmitt, J., Schwander, J., Siegenthaler, U., Siggaard-Andersen, M.L., Spahni, R., Steffensen, J.P., Stenni, B., Stocker, T.F., Tison, J.L., Traversi, R., Udisti, R., Valero-Delgado, F., van den Broeke, M.R., van de Wal, R.S.W., Wagenbach, D., Wegner, A., Weiler, K., Wilhelms, F., Winther, J.G., Wolff, E., Members, E.C., 2006. One-to-one coupling of glacial climate variability in Greenland and Antarctica. Nature 444, 195-198. 10.1038/Nature05301

Barker, S., Diz, P., vautravers, M., Pike, J., Knorr, G., Hall, I.R., Broecker, W., 2009. Interhemispheric Atlantic seesaw response during the last deglaciation. Nature 457, 1097 1102.

Barker, S., Greaves, M., Elderfield, H., 2003. A study of cleaning procedures used for foraminiferal $\mathrm{Mg} / \mathrm{Ca}$ paleothermometry. Geochem. Geophys. Geosyst. 4, 8407. doi:10.1029/2003GC000559

Barker, S., Knorr, G., Vautravers, M., Diz, P., Skinner, L., 2010. Extreme deepening of the Atlantic overturning circulation during deglaciation. Nature Geoscience 3, 567-571.

Bianchi, C., Gersonde, R., 2004. Climate evolution at the last deglaciation: the role of the Southern Ocean. Earth Planet. Sci. Lett. 228, 407-424. 10.1016/j.eps1.2004.10.003

Bradtmiller, L., Anderson, R.F., Sachs, J., Fleisher, M.Q., 2010. A deeper respired carbon pool in the glacial equatorial Pacific Ocean. Earth Planet. Sci. Lett., doi:10.1016/j.epsl.2010.1009.1022.

Broecker, W., 1982. Glacial to interglacial changes in ocean chemistry. Progr. Oceanogr. 2, 151-197.

Broecker, W., Clark, E., Barker, S., Hajdas, I., Bonani, G., Moreno, E., 2007. Radiocarbon age of late glacial deep water from the equatorial Pacific. Paleoceanogr. 22, PA2206, doi:2210.1029/2006PA001359.

Broecker, W., Maier-Reimer, E., 1992. The influence of air and sea exchange on the carbon isotope distribution in the sea. Glob. Biogeochem. Cycle 6, 315-320. 
Broecker, W., Putnam, A.E., 2012. How did the hydrologic cycle respond to the two-phase mystery interval? Quat. Sci. Rev. 57, 17-25. DOI 10.1016/j.quascirev.2012.09.024

Broecker, W.S., Peng, T.H., 1987. The role of $\mathrm{CaCO}_{3}$ compensation in the glacial to interglacial atmospheric $\mathrm{CO}_{2}$ change. Glob. Biogeochem. Cycle 1, 15-29.

Brown, R.E., Anderson, L.D., Thomas, E., Zachos, J.C., 2011. A core-top calibration of B/Ca in the benthic foraminifers Nuttallides umbonifera and Oridorsalis umbonatus: A proxy for Cenozoic bottom water carbonate saturation. Earth Planet. Sci. Lett. 310, 360-368. 10.1016/j.eps1.2011.08.023

Burke, A., Robinson, L.F., 2012. The Southern Ocean's role in carbon exchange during the last deglaciation. Science, doi:10.1126/science.1208163.

Charles, C.D., Fairbanks, R.G., 1992. Evidence from Southern-Ocean Sediments for the Effect of North-Atlantic Deep-Water Flux on Climate. Nature 355, 416-419. $10.1038 / 355416 \mathrm{a} 0$

Corliss, B.H., 1985. Microhabitats of benthic foraminifera within deep-sea sediments. Nature $314,435-438$.

Curry, W.B., Oppo, D., 2005. Glacial water mass geometry and the distribution of $\delta^{13} \mathrm{C}$ of $\Sigma \mathrm{CO}_{2}$ in the western Altantic Ocean. Paleoceanogr. 20, PA1017, doi:1010.1029/2004PA001021.

Divine, D.V., Koc, N., Isaksson, E., Nielsen, S., Crosta, X., Godtliebsen, F., 2010. Holocene Antarctic climate variability from ice and marine sediment cores: Insights on oceanatmosphere interaction. Quat. Sci. Rev. 29, 303-312. 10.1016/j.quascirev.2009.11.012

Elsig, J., Schmitt, J., Leuenberger, D., Schneider, R.R., Eyer, M., Leuenberger, M., Joos, F., Fischer, H., Stocker, T.F., 2009. Stable isotope constraints on Holocene carbon cycle changes from an Antarctic ice core. Nature 461, 507-510.

Farrell, J.W., Prell, W.L., 1989. Climatic change and $\mathrm{CaCO}_{3}$ preservation: an 800,000 year bathymetric reconstruction from the central equatorial Pacific Ocean. Paleoceanogr. 4, 447466.

Fleisher, M.Q., Anderson, R.F., 2003. Assessing the collection efficiency of Ross Sea sediment traps using Th-230 and Pa-231. Deep-Sea Research Part Ii-Topical Studies in Oceanography 50, 693-712. Pii S0967-0645(02)00591-X

Doi 10.1016/S0967-0645(02)00591-X

Foster, G.L., 2008. Seawater $\mathrm{pH}, \mathrm{pCO}_{2}$ and $\left[\mathrm{CO}_{3}{ }^{2-}\right]$ variations in the Caribbean Sea over the last $130 \mathrm{kyr}$; a boron isotope and $\mathrm{B} / \mathrm{Ca}$ study of planktic foraminifera. Earth Planet. Sci. Lett. 271, 254-266. doi: 210.1016/j.eps1.2008.1004.1015.

Galbraith, E.D., Jaccard, S.L., Pedersen, T.F., Sigman, D.M., Haug, G.H., Cook, M., Southon, J.R., Francois, R., 2007. Carbon dioxide release from the North Pacific abyss during the last deglaciation. Nature 449, 890-893.

He, F., Shakun, J.D., Clark, P.U., Carlson, A.E., Liu, Z.Y., Otto-Bliesner, B.L., Kutzbach, J.E., 2013. Northern Hemisphere forcing of Southern Hemisphere climate during the last deglaciation. Nature 494, 81-85. Doi 10.1038/Nature11822

Ho, S.L., Mollenhauer, G., Lamy, F., Martinez-Garcia, A., Mohtadi, M., Gersonde, R., Hebbeln, D., Nunez-Ricardo, S., Rosell-Mele, A., Tiedemann, R., 2012. Sea surface temperature variability in the Pacific sector of the Southern Ocean over the past $700 \mathrm{kyr}$. Paleoceanogr. 27. Artn Pa4202, 10.1029/2012pa002317

Hodell, D.A., Charles, C.D., Sierro, F.J., 2001. Late Pleistocene evolution of the ocean's carbonate system. Earth Planet. Sci. Lett. 192, 109-124. 
Howard, W.R., Prell, W.L., 1994. Late Quaternary $\mathrm{CaCO}_{3}$ production and preservation in the Southern Ocean - Implications for oceanic and atmospheric carbon cycling. Paleoceanogr. 9, 453-482.

Jaccard, S.L., Galbraith, E.D., 2012. Large climate-driven changes of oceanic oxygen concentrations during the last deglaciation. Nature Geoscience 5, 151-156. 10.1038/Ngeo1352

Karlin, R., Lyle, M., Zahn, R., 1992. Carbonate Variations in the Northeast Pacific during the Late Quaternary. Paleoceanogr. 7, 43-61. Doi 10.1029/91pa03077

Key, R.M., Kozyr, A., Sabine, C.L., Lee, K., Wanninkhof, R., Bullister, J.L., Feely, R.A., Millero, F.J., Mordy, C., Peng, T.H., 2004. A global ocean carbon climatology: Results from Global Data Analysis Project (GLODAP). Glob. Biogeochem. Cycle 18. 10.1029/2004GB002247

Lea, D., Bijam, J., Spero, H., Archer, D., 1999. Implications of a carbonate ion effect on shell carbon and oxygen isotopes for glacial ocean conditions, In: Fischer, G., Wefer, G. (Eds.), Use of Proxies in Paleoceanography: Examples from the South Atlantic. Springer-Verlag, Berlin Heidelberg, pp. 513-522.

Lemieux-Dudon, B., Blayo, E., Petit, J.R., Waelbroeck, C., Svensson, A., Ritz, C., Barnola, J.M., Narcisi, B.M., Parrenin, F., 2010. Consistent dating for Antarctic and Greenland ice cores. Quat. Sci. Rev. 29, 8-20.

Liu, Z., Otto-Bliesner, B.L., He, F., Brady, E.C., Tomas, R., Clark, P.U., Carlson, A.E., Lynch-Stieglitz, J., Curry, W., Brook, E., Erickson, D., Jacob, R., Kutzbach, J., Cheng, J., 2009. Transient Simulation of Last Deglaciation with a New Mechanism for Bolling-Allerod Warming. Science 325, 310-314. DOI 10.1126/science.1171041

Lund, D.C., Adkins, J.F., Ferrari, R., 2011. Abyssal Atlantic circulation during the Last Glacial Maximum: Constraining the ratio between transport and vertical mixing. Paleoceanogr. 26. 10.1029/2010pa001938

Lutze, G.F., Thiel, H., 1989. Epibenthic foraminifera from elevated microhabitats: Cibicidoides wuellerstorfi and Planulina ariminensis. J. Foraminiferal Res. 19, 153-158.

Lyle, M., Mix, A.C., Ravelo, A.C., Andreasen, D., Heuser, L., Olivarez, A., 2000. Millennialscale $\mathrm{CaCO}_{3}$ and $\mathrm{C}_{\text {org }}$ events along the Northern and central California margins: stratigraphy and origins, In: Lyle, M., Koizumi, I., Richter, C., Moore, T.C. (Eds.), Proceedings of the Ocean Drilling Program, Scientific Results, pp. 163-182.

Mackensen, A., 2012. Strong thermodynamic imprint on Recent bottom-water and epibenthic delta C-13 in the Weddell Sea revealed: Implications for glacial Southern Ocean ventilation. Earth Planet. Sci. Lett. 317, 20-26. DOI 10.1016/j.eps1.2011.11.030

Mackensen, A., Hubberten, H.-W., Bickert, T., Fischer, G., Fütterer, D.K., 1993. The $\delta^{13} \mathrm{C}$ in benthic foraminiferal tests of Fontbotia wuellerstorfi (schwager) relative to the $\delta^{13} \mathrm{C}$ of dissolved inorganic carbon in Souther Ocean deep water: Implications for glacial ocean circulation models. Paleoceanogr. 8, 587-610.

McCave, I.N., Carter, L., Hall, I.R., 2008. Glacial-interglacial changes in water mass structure and flow in the SW Pacific Ocean. Quat. Sci. Rev. 27, 1886-1908. 10.1016/j.quascirev.2008.07.010

McGlone, M.S., Turney, C.S.M., Wilmshurst, J.M., Renwick, J., Pahnke, K., 2010. Divergent trends in land and ocean temperature in the Southern Ocean over the past 18,000 years. Nature Geoscience 3, 622-626. 10.1038/Ngeo931

McManus, J., Francois, R., Gherardi, J.-M., Keigwin, L., Brown-Leger, S., 2004. Collapse and rapid resumption of Atlantic meridional circulation linked to deglacial climate changes. Nature 428, 834-837. 
Menviel, L., Joos, F., 2012. Toward explaining the Holocene carbon dioxide and carbon isotope records: Results from transient ocean carbon cycle-climate simulations. Paleoceanogr. 27. $10.1029 / 2011 \mathrm{pa} 002224$

Menviel, L., Timmermann, A., Timm, O.E., Mouchet, A., 2011. Deconstructing the Last Glacial termination: the role of millennial and orbital-scale forcings. Quat. Sci. Rev. 30, 11551172. 10.1016/j.quascirev.2011.02.005

Monnin, E., Indermuhle, A., Dällenbach, A., Fluckiger, J., Stauffer, B., Stocker, T.F., Raynaud, D., Barnola, J.M., 2001. Atmospheric $\mathrm{CO}_{2}$ Concentrations over the Last Glacial Termination. Science 291, 112-114.

Morrison, A.K., Hogg, A.M., 2013. On the Relationship between Southern Ocean Overturning and ACC Transport. J Phys Oceanogr 43, 140-148. Doi 10.1175/Jpo-D-12-057.1

Ninnemann, U.S., Charles, C.D., 2002. Changes in the mode of Southern Ocean circulation over the last glacial cycle revealed by foraminiferal stable isotopic variability. Earth Planet. Sci. Lett. 201, 383-396.

Opdyke, B.N., Walker, J.C.G., 1992. Return of the Coral-Reef Hypothesis - Basin to Shelf Partitioning of $\mathrm{CaCO}_{3}$ and Its Effect on Atmospheric $\mathrm{CO}_{2}$. Geology 20, 733-736.

Piotrowski, A., Galy, A., Nicholl, J.A.L., Roberts, N., Wilson, D.J., Clegg, J.A., Yu, J., 2012. Reconstructing deglacial North and South Atlantic deep water sourcing using foraminiferal Nd isotopes. Earth Planet. Sci. Lett. 357-358, 289-297.

Piotrowski, A., Goldstein, S.J., Hemming, S.R., Fairbanks, R.G., 2005. Temporal Relationships of carbon cycling and ocean circulation at glacial boundaries. Science 307, 1933-1938.

Putnam, A.E., Denton, G.H., Schaefer, J.M., Barrell, D.J.A., Andersen, B.G., Finkel, R.C., Schwartz, R., Doughty, A.M., Kaplan, M.R., Schluchter, C., 2010. Glacier advance in southern middle-latitudes during the Antarctic Cold Reversal. Nature Geoscience 3, 700-704. 10.1038/Ngeo962

Rae, J.W.B., Foster, G.L., Schmidt, D.N., Elliott, T., 2011. Boron isotopes and B/Ca in benthic foraminifera: Proxies for the deep ocean carbonate system. Earth Planet. Sci. Lett. 302, 403-413. 10.1016/j.eps1.2010.12.034

Raitzsch, M., Hathorne, E.C., Kuhnert, H., Groeneveld, J., Bickert, T., 2011. Modern and late Pleistocene $\mathrm{B} / \mathrm{Ca}$ ratios of the benthic foraminifer Planulina wuellerstorfi determined with laser ablation ICP-MS. Geology 39, 1039-1042. 10.1130/G32009.1

Reimer, P.J., Baillie, M.G.L., Bard, E., Bayliss, A., Beck, J.W., Blackwell, P.G., Ramsey, C.B., Buck, C.E., Burr, G.S., Edwards, R.L., Friedrich, M., Grootes, P.M., Guilderson, T.P., Hajdas, I., Heaton, T.J., Hogg, A.G., Hughen, K.A., Kaiser, K.F., Kromer, B., McCormac, F.G., Manning, S.W., Reimer, R.W., Richards, D.A., Southon, J.R., Talamo, S., Turney, C.S.M., van der Plicht, J., Weyhenmeyer, C.E., 2009. Intcal09 and Marine09 radiocarbon age calibration curves, 0-50,000 years cal BP. Radiocarbon 51, 1111-1150.

Rickaby, R.E.M., Elderfield, H., Roberts, N., Hillenbrand, C.-D., Mackensen, A., 2010. Evidence for elevated alkalinity in the glacial Southern Ocean. Paleoceanogr. 25, PA1209, doi:1210.1029/2009PA001762.

Ridgwell, A.J., Watson, A.J., Maslin, M.A., Kaplan, J.O., 2003. Implications of coral reef buildup for the controls on atmospheric $\mathrm{CO}_{2}$ since the Last Glacial Maximum. Paleoceanogr. 18. 10.1029/2003PA000893

Sachs, J.P., Anderson, R.F., 2003. Fidelity of alkenone paleotemperatures in southern Cape Basin sediment drifts. Paleoceanogr. 18. Artn 1082, Doi 10.1029/2002pa000862 
Schmitt, J., Schneider, R., Elsig, J., Leuenberger, D., Lourantou, A., Chappellaz, J., Kohler, P., Joos, F., Stocker, T.F., Leuenberger, M., Fischer, H., 2012. Carbon isotope constraints on the deglacial $\mathrm{CO}_{2}$ rise from ice cores. Science, doi 10.1126/science.1217161.

Sigman, D.M., Boyle, E.A., 2000. Glacial/interglacial variations in atmospheric carbon dioxide. Nature 407, 859-869.

Sigman, D.M., Hain, M.P., Haug, G.H., 2010a. The polar ocean and glacial cycles in atmospheric $\mathrm{CO}_{2}$ concentration. Nature 466, 47-55.

Sigman, D.M., Hain, M.P., Haug, G.H., 2010b. The polar ocean and glacial cycles in atmospheric $\mathrm{CO}_{2}$ concentration. Nature 466, 47-55. 10.1038/Nature09149

Skinner, L., Fallon, S.J., Waelbroeck, C., Michel, E., Barker, S., 2010. Ventilation of the Deep Southern Ocean and Deglacial $\mathrm{CO}_{2}$ Rise. Science 328, 1147-1151.

Stuiver, M., Reimer, P.J., 1993. Extended ${ }^{14} \mathrm{C}$ data-base and revised Calib $3.014 \mathrm{C}$ age calibration program. Radiocarbon 35, 215-230.

Toggweiler, J.R., Russell, J.L., Carson, S.R., 2006. Midlatitude westerlies, atmospheric $\mathrm{CO}_{2}$, and climate change during the ice ages. Paleoceanogr. 21, PA2005, doi:2010.1029/2005PA001154, 002006.

Vecsei, A., Berger, W.H., 2004. Increase of atmospheric $\mathrm{CO}_{2}$ during deglaciation: Constraints on the coral reef hypothesis from patterns of deposition. Glob. Biogeochem. Cycle 18. $10.1029 / 2003 \mathrm{gb} 002147$

Yu, J., Anderson, R.F., Jin, Z.D., Rae, J., Opdyke, B.N., Eggins, S., 2013a. Responses of the deep ocean carbonate system to carbon reorganization during the Last Glacial-interglacial cycle. Quat. Sci. Rev. 76, 39-52. http://dx.doi.org/10.1016/j.quascirev.2013.06.020

Yu, J., Broecker, W., Elderfield, H., Jin, Z.D., McManus, J., Zhang, F., 2010a. Loss of carbon from the deep sea since the Last Glacial Maximum. Science 330, 1084-1087, doi: 1010.1126/science.1193221.

Yu, J., Foster, G.L., Elderfield, H., Broecker, W.S., Clark, E., 2010b. An evaluation of benthic foraminiferal $\mathrm{B} / \mathrm{Ca}$ and delta(11)B for deep ocean carbonate ion and $\mathrm{pH}$ reconstructions. Earth Planet. Sci. Lett. 293, 114-120. 10.1016/j.eps1.2010.02.029

Yu, J., Thornalley, D.J.R., Rae, J., McCave, I.N., 2013b. Calibration and application of B/Ca, $\mathrm{Cd} / \mathrm{Ca}$, and $\delta^{11} \mathrm{~B}$ in Neogloboquadrina pachyderma (sinistral) to constrain $\mathrm{CO}_{2}$ uptake in the subpolar North Atlantic during the last deglaciation. Paleoceanogr. 10.1002/palo.20024

Yu, J.M., Day, J., Greaves, M., Elderfield, H., 2005. Determination of multiple element/calcium ratios in foraminiferal calcite by quadrupole ICP-MS. Geochem. Geophys. Geosyst. 6, Q08P01, doi:10.1029/2005GC000964.

Yu, J.M., Elderfield, H., 2007. Benthic foraminiferal B/Ca ratios reflect deep water carbonate saturation state. Earth Planet. Sci. Lett. 258, 73-86, doi: 10.1016/j.epsl.2007.1003.1025.

Yu, J.M., Elderfield, H., Greaves, M., Day, J., 2007. Preferential dissolution of benthic foraminiferal calcite during laboratory reductive cleaning. Geochem. Geophys. Geosyst. 8, Q06016, doi:06010.01029/02006GC001571.

Yu, J.M., Elderfield, H., Piotrowski, A., 2008. Seawater carbonate ion- $\delta^{13} \mathrm{C}$ systematics and application to glacial-interglacial North Atlantic ocean circulation. Earth Planet. Sci. Lett. 271, 209-220. doi:210.1016/j.epsl.2008.1004.1010.

Yu, J.M., Foster, G.L., Elderfield, H., Broecker, W.S., Clark, E., 2010c. An evaluation of benthic foraminiferal $\mathrm{B} / \mathrm{Ca}$ and $\delta^{11} \mathrm{~B}$ for deep ocean carbonate ion and $\mathrm{pH}$ reconstructions. Earth Planet. Sci. Lett. 293, 114-120, 110.1016/j.epsl.2010.1002.1029 
Fig. 1. Locations of core TNO57-21 and two cores in the Western Equatorial Pacific (WEP) against the pre-industrial seawater $\left[\mathrm{CO}_{3}{ }^{2-}\right]$. Inset shows the locations of hydrographic sites used for the $\left[\mathrm{CO}_{3}^{2-}\right]$ section (Key et al., 2004). The map was generated using Ocean Data View (http://odv.awi-bremerhaven.de.). Three key water masses are indicated: NADW $=$ North Atlantic Deep Water, LCDW $=$ Lower Circumpolar Deep Water, and NPDW = North Pacific Deep Water.

Fig. 2. Data from core TNO57-21. (A) C. wuellerstorfi B/Ca and reconstructed deep water $\left[\mathrm{CO}_{3}{ }^{2-}\right]$ (red circles) with b-spline smoothing (red curve). The error bar 801 represents the average $2 \sigma\left[\mathrm{CO}_{3}{ }^{2-}\right]$ error from analytical uncertainty in $\mathrm{B} / \mathrm{Ca}$. (B) $\% \mathrm{CaCO}_{3}$ (green crosses) and ${ }^{230} \mathrm{Th}$-normalized $\mathrm{CaCO}_{3}$ flux (blue squares) (Sachs and Anderson, 2003; this study). (C) benthic $\delta^{13} \mathrm{C}$ (Ninnemann and Charles, 2002). radiocarbon dates.

Fig. 3. Vertical seawater $\left[\mathrm{CO}_{3}{ }^{2-}\right]$ distributions during the LGM and today. LGM data are for the North Atlantic (Yu et al., 2010a), equatorial (EQ) Atlantic (Raitzsch et al.,

810 al., 2010a). Error bars represent 1 standard deviation of values from the LGM.

811 Modern global seawater $\left[\mathrm{CO}_{3}{ }^{2-}\right]$ is from the eWOCE dataset (http://www.ewoce.org/).

812 Squares along the top $\mathrm{x}$-axis represent surface water $\left[\mathrm{CO}_{3}{ }^{2-}\right]$ reconstructions for the 813 tropical Atlantic during the Holocene and the LGM (Foster, 2008). Little change in 
814 deep Indo-Pacific $\left[\mathrm{CO}_{3}{ }^{2-}\right]$ is also supported by foraminiferal assemblage analyses 815 (Anderson and Archer, 2002).

817 Fig. 4. Marine and atmospheric records over the past 28 kyr. (A) North Atlantic Deep 818 Water formation strength from $\mathrm{Pa} / \mathrm{Th}$ (McManus et al., 2004). (B) $\left[\mathrm{CO}_{3}{ }^{2-}\right]$ at TNO5781921 (this study) and GGC48 (Yu et al., 2010a). (C) Benthic $\delta^{13} \mathrm{C}$ at TNO57820 21(Ninnemann and Charles, 2002) and GGC48 (Yu et al., 2010a). (D) $\Delta \Delta^{14} \mathrm{C}$, the 821 benthic-atmospheric $\Delta^{14} \mathrm{C}$ offset, for TNO57-21 (Barker et al., 2010) and MD01-2386 822 (Broecker et al., 2007). In (B-D), red solid circles are for TNO57-21, while green 823 empty symbols are for WEP cores. (E) Opal flux in the Antarctic Zone (Anderson et 824 al., 2009). (F) atmospheric $\Delta^{14} \mathrm{C}$ (Reimer et al., 2009). (G) atmospheric $\delta^{13} \mathrm{CO}_{2}$ 825 (Schmitt et al., 2012). (H) atmospheric $\mathrm{CO}_{2}$ (Monnin et al., 2001). (I) EDML ice core $826 \delta^{18} \mathrm{O}$ (Barbante et al., 2006). Ice core data are on the age model of (Lemieux-Dudon et al., 2010). Error bars in (B, C, F, G) are $1 \sigma$ uncertainties, the ellipse in (D) represents approximate average $2 \sigma$ error, and curves in $(B, G)$ are b-spline smoothing. Triangles at base represent radiocarbon dates for TNO57-21 (SI Text) (Barker et al., 2010).

Fig. 5. Bathymetric distributions of $\delta^{13} \mathrm{C}$ during the LGM (A) and today (B). The 832 large $\delta^{13} \mathrm{C}$ dissimilarity shown in (A) suggests a poorly mixed deep ocean during the 833 LGM. This is in stark contrast to much reduced $\delta^{13} \mathrm{C}$ variability in the modern ocean 834 (B), where deep waters are well mixed. There must have been an increase in lateral exchange of deep water from the LGM to today. Our data (Fig. 4) explain when (HS1) and how (increased lateral mixing) this increase occurred, and provide new insights 
into the global carbon cycle during the last deglaciation. Data source: LGM benthic $\delta^{13} \mathrm{C}$ (curves in $\mathrm{A}$ ) are from (McCave et al., 2008) and references therein; modern hydrographic data are compiled in the eWOCE dataset (http://www.ewoce.org/) and are for sites (curves in B) close to the locations of cores used for the LGM profile reconstructions in (A): S Atlantic - sites $7320 / 16288\left(11.5^{\circ} \mathrm{E}, 49.6^{\circ} \mathrm{S}\right), \mathrm{S}$ Indian - sites $7516 / 7522\left(57.9^{\circ} \mathrm{E}, 47.7^{\circ} \mathrm{S}\right)$, S. Pacific - sites $11724 / 11727 / 7426\left(175.9^{\circ} \mathrm{E}, 30.9^{\circ} \mathrm{S}\right)$, EQ Pacific - site $11690\left(165^{\circ} \mathrm{E}, 0^{\circ} \mathrm{N}\right)$. LGM and Holocene averages for cores GGC48 and TNO57-21 are shown by blue circles and red squares with error bars representing 1 standard deviation of values from the designated age intervals, respectively.

Fig. 6. Schematic illustration of processes affecting deglacial interocean deep water exchange and $\mathrm{CO}_{2}$ degassing. (A) LGM. (B) HS1. Compared to the LGM, deep South Atlantic-Pacific carbon exchange during HS1 was enhanced by increased meridional (isopycnal) mixing (Morrison and Hogg, 2013) and by increased Antarctic Circumpolar Current flow (Ho et al., 2012), probably due to a poleward shift and/or intensification of Southern Westerlies (Anderson et al., 2009; Toggweiler et al., 2006). By distributing $\mathrm{CO}_{2}$-rich deep Pacific waters around Antarctica, increased interocean mixing would have augmented $\mathrm{CO}_{2}$ degassing in the Southern Ocean during the breakdown of vertical stratification (Anderson et al., 2009; Burke and Robinson, 2012; Sigman et al., 2010b) and sea ice retreat (Bianchi and Gersonde, 2004; Divine et al., 2010) during HS1. Thicker lines indicate increased fluxes or wind stress. Figure is modified from Charles and Fairbanks (1992). 
Figures

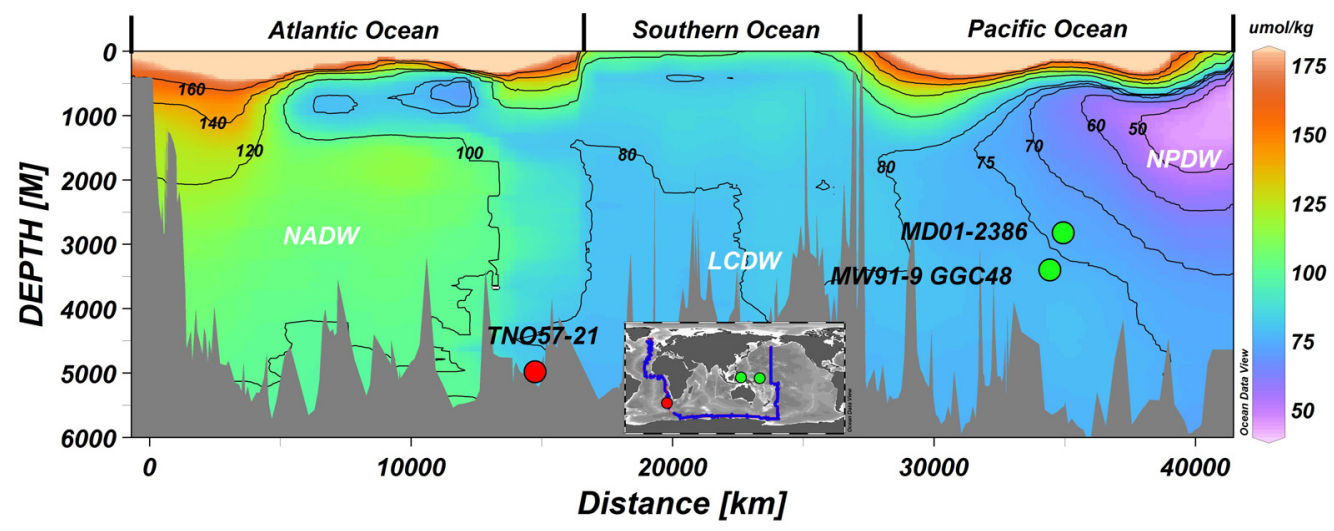

Fig. 1 


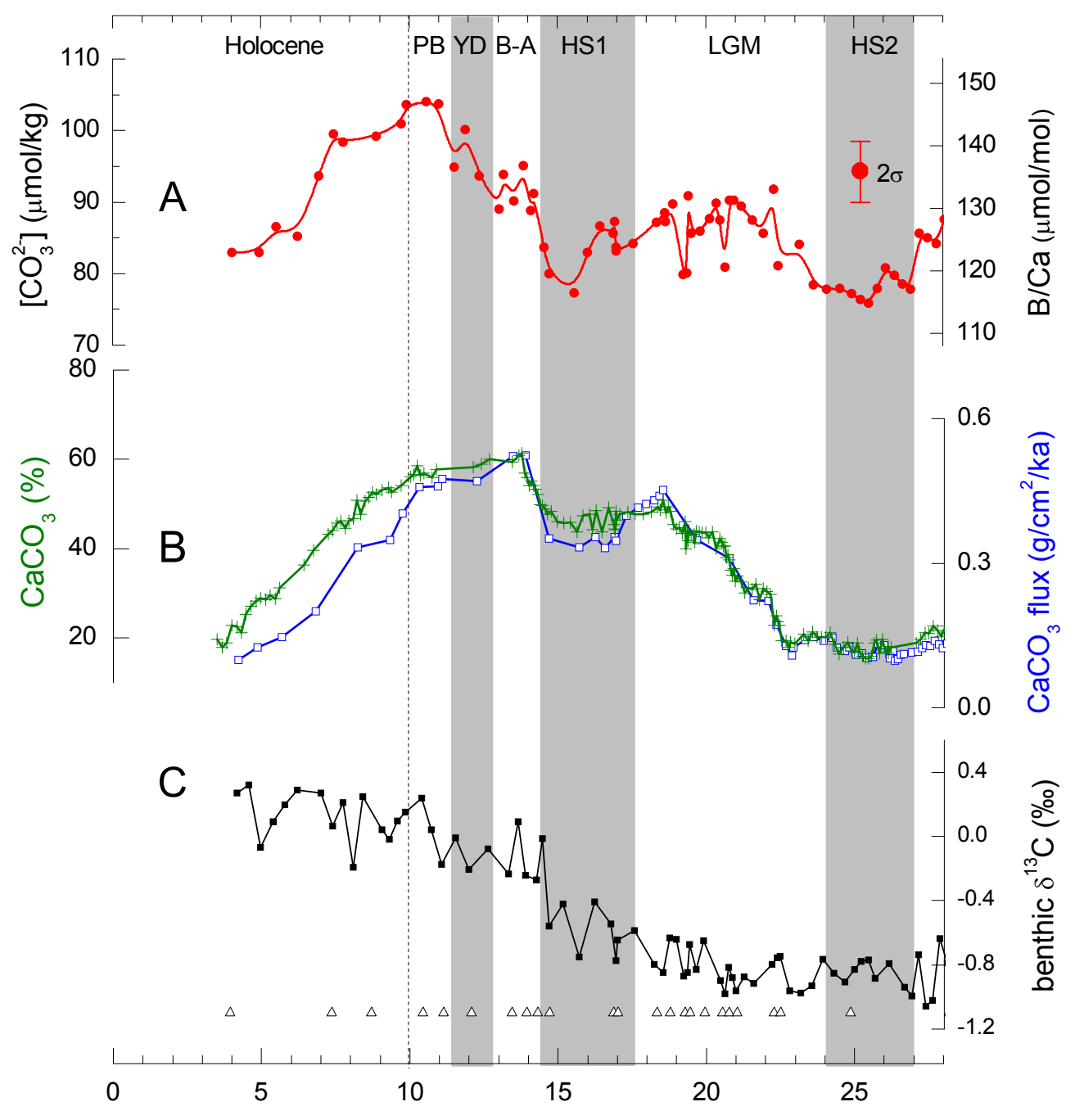

Age (kyr)

Fig. 2 


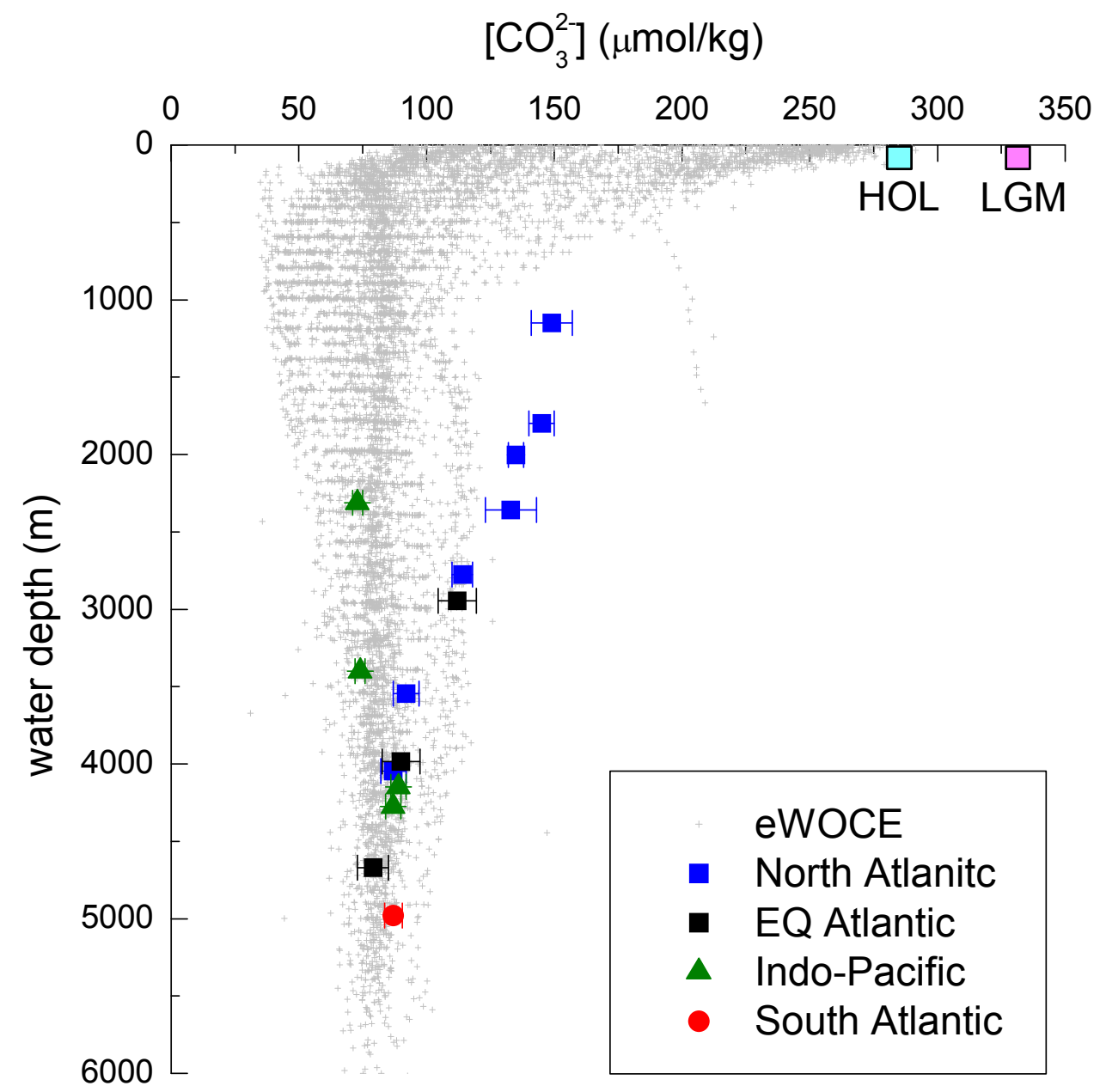

Fig. 3 


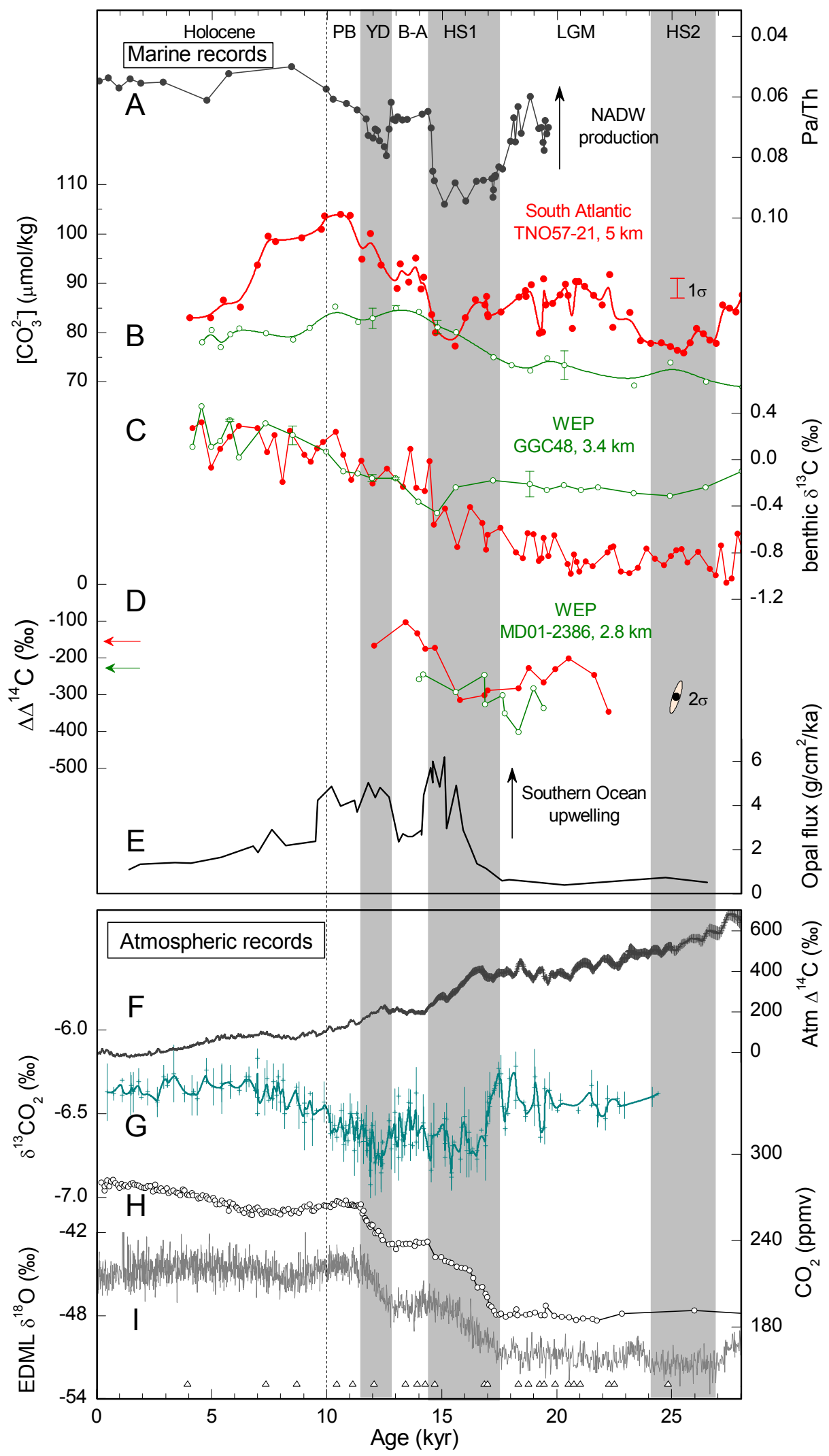

Fig. 4 


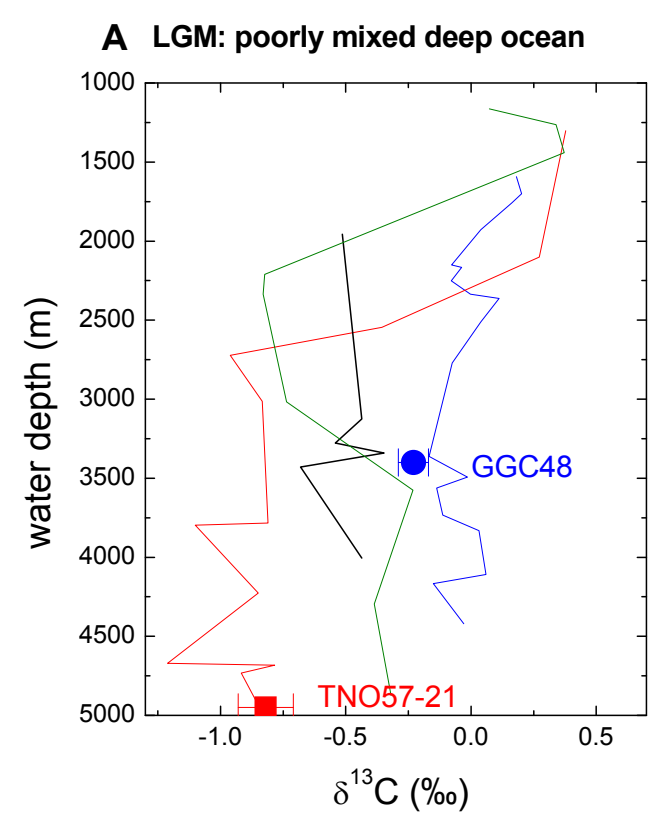

B Today: well mixed deep ocean

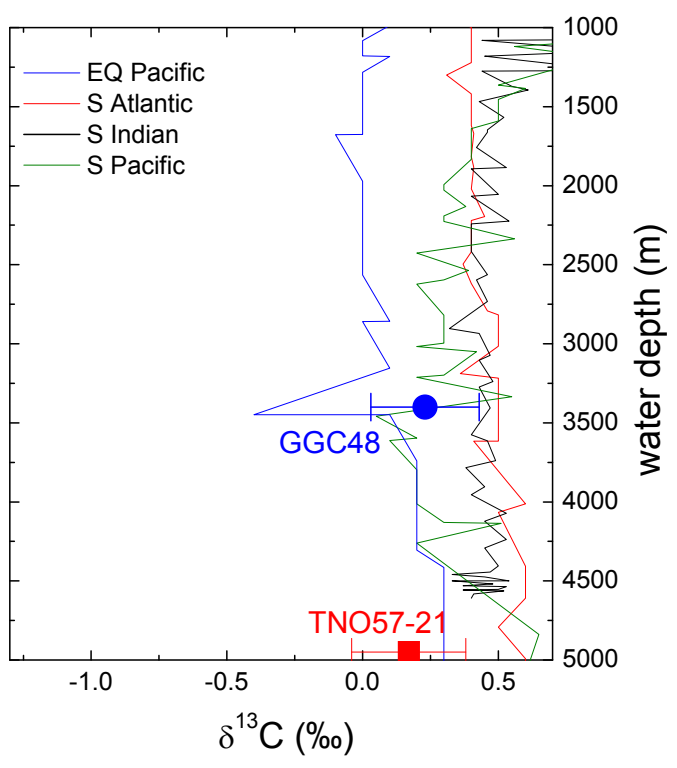

Fig. 5 
A LGM

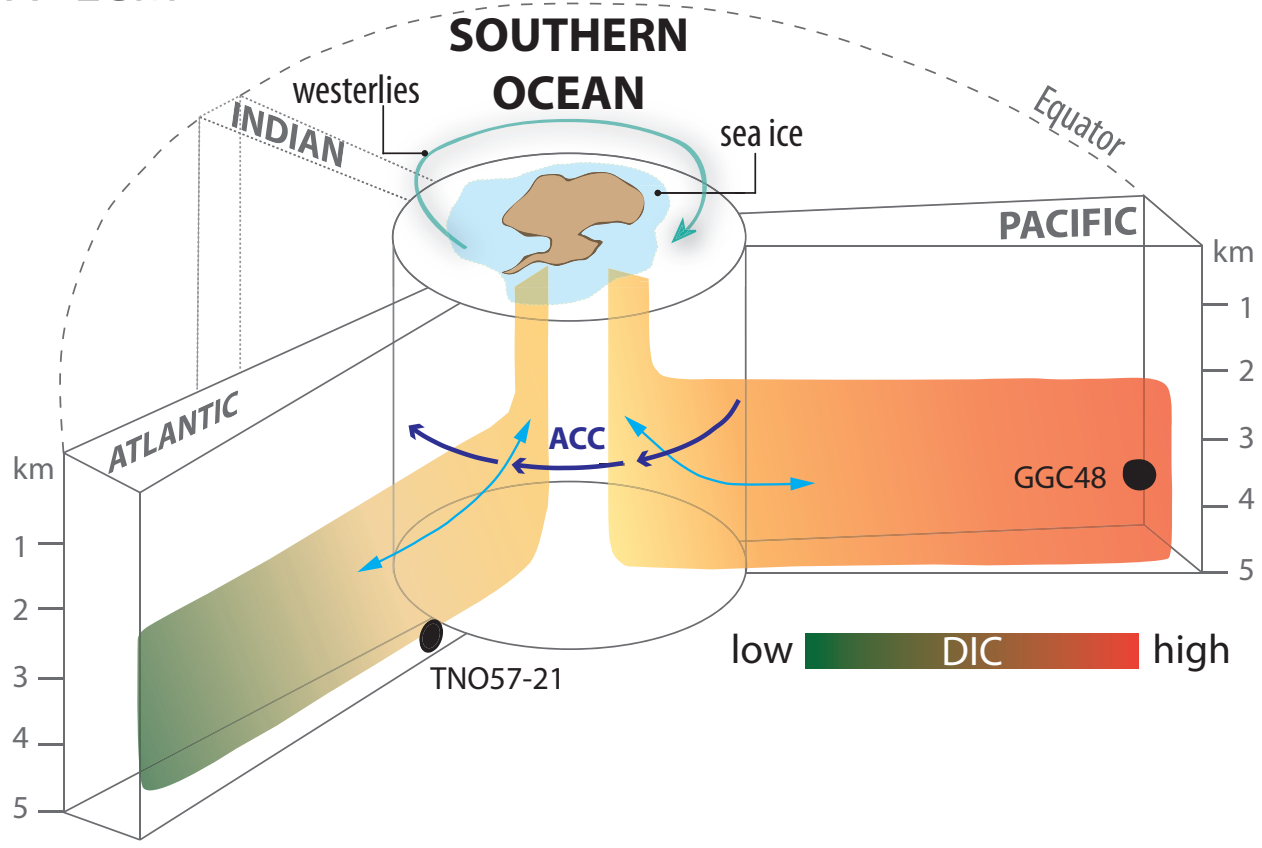

B HS1

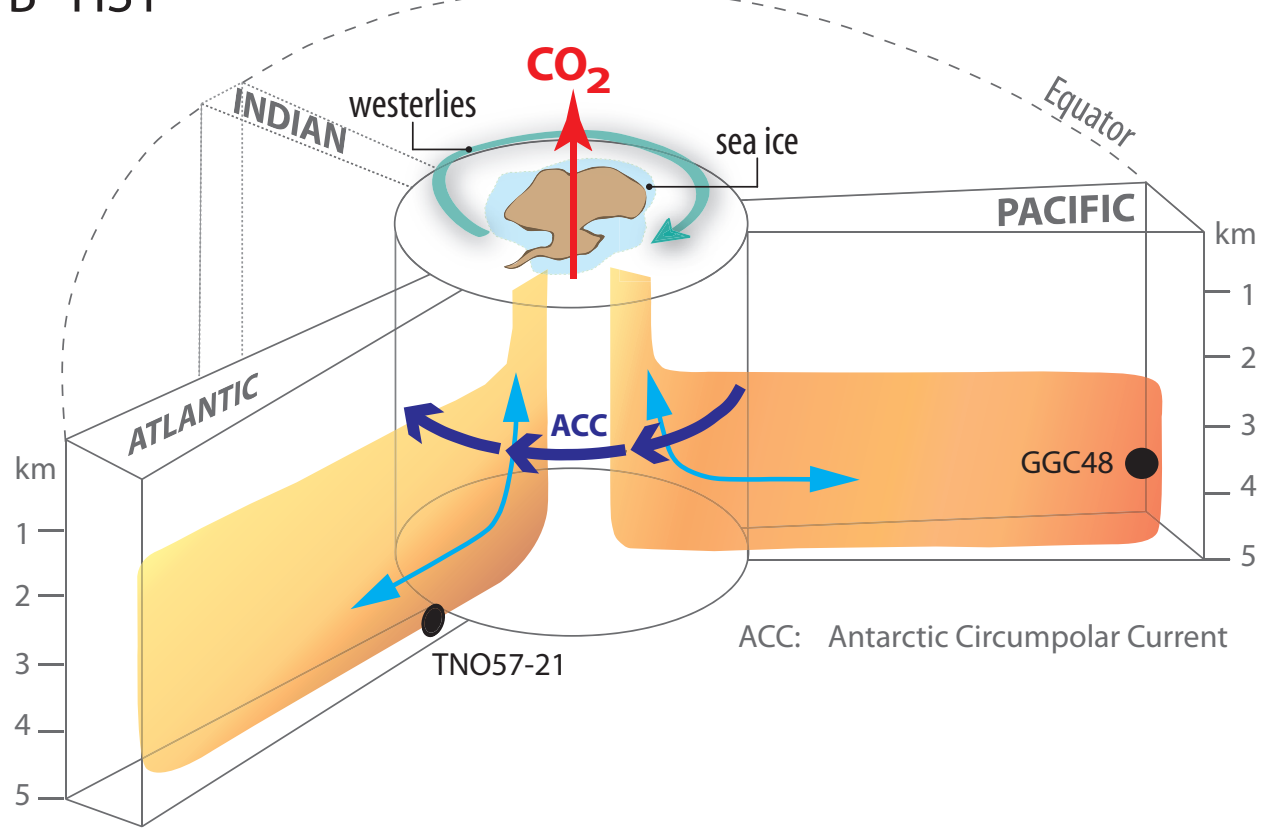

Fig. 6 